\title{
Suppression of $\beta 1$-Integrin in Gonadotropin-Releasing Hormone Cells Disrupts Migration and Axonal Extension Resulting in Severe Reproductive Alterations
}

\author{
Jyoti Parkash, ${ }^{1,2 *}$ Irene Cimino, ${ }^{1,2 *}$ Nicoletta Ferraris, ${ }^{3}$ Filippo Casoni, ${ }^{1,2}$ Susan Wray, ${ }^{4}$ Hélène Cappy, ${ }^{1,2}$ \\ Vincent Prevot, ${ }^{1,2}$ and Paolo Giacobini ${ }^{1,2,3}$ \\ ${ }^{1}$ Inserm U837, Jean-Pierre Aubert Research Center, Development and Plasticity of the Postnatal Brain and 2UDSL, School of Medicine, Place de Verdun, \\ F-59045, Lille Cedex, France, ${ }^{3}$ Department Human and Animal Biology, University of Turin, Turin, 10123 Italy, and ${ }^{4}$ Cellular and Developmental \\ Neurobiology Section, National Institute of Neurological Disorders and Stroke-National Institutes of Health, Bethesda, Maryland 20892
}

Reproduction in mammals is dependent on the function of hypothalamic neurons whose axons project to the hypothalamic median eminence $(\mathrm{ME})$ where they release gonadotropin-releasing hormone $(\mathrm{GnRH})$ into a specialized capillary network for delivery to the anterior pituitary. These neurons originate prenatally in the nasal placode and migrate into the forebrain along the olfactoryvomeronasal nerves. The complex developmental events leading to the correct establishment of the $\mathrm{GnRH}$ system are tightly regulated by the specific spatiotemporal expression patterns of guidance cues and extracellular matrix molecules, the functions of which, in part, are mediated by their binding to $\beta 1$-subunit-containing integrins. To determine the biological role of these cell-surface proteins in reproduction, Cre/LoxP technology was used to generate GnRH neuron-specific $\beta 1$-integrin conditional KO (GnRH-Itgb1 ${ }^{-l-}$ ) mice. Loss of $\beta 1$-integrin signaling impaired migration of GnRH neurons, their axonal extension to the ME, timing of pubertal onset, and fertility in these mice. These results identify $\beta 1$-integrin as a gene involved in normal development of the GnRH system and demonstrate a fundamental role for this protein in acquisition of normal reproductive competence in female mice.

\section{Introduction}

Reproductive competence in mammals is centrally regulated through the hypothalamic — pituitary-gonadal axis and depends on gonadotropin-releasing hormone (GnRH) secretion (Wray, 2010). These neurons project to the median eminence (ME) of the hypothalamus where GnRH is released into the pituitary portal blood for delivery to the anterior pituitary, eliciting the secretion of luteinizing hormone ( $\mathrm{LH})$ and follicle-stimulating hormone (FSH) (Wray, 2010). GnRH-secreting neurons originate in the nasal placode during embryonic development and migrate to the hypothalamus apposed to olfactory-vomeronasal nerves (Schwanzel-Fukuda and Pfaff, 1989; Wray et al., 1989).

\footnotetext{
Received June 28, 2012; revised Sept. 25, 2012; accepted Sept. 28, 2012.

Author contributions: P.G. designed research; J.P., I.C., N.F., and H.C. performed research; F.C. and S.W. contributed unpublished reagents/analytic tools; J.P. and I.C. analyzed data; V.P. and P.G. wrote the paper.

This work was supported by Compagnia di San Paolo, Turin, Italy (grant number 2008.1224 to P.G.); the Institut National de la Santé et de la Recherche Médicale, Inserm, France (grant number U837); Agence Nationale de la Recherche, ANR, France (grant numbers ANR-2010-JCJC-1404-01 to P.G. and ANR-09-BLAN-0267 to V.P.); the University of Lille 2, Lille, France (Appel a' Projets du Conseil Scientifique de I'Universite' Lille 2 to P.G.); and the Intramural Research Program of the National Institute of Neurological Disorders and Stroke-National Institutes of Health. We thank Meryem Tardivel of the Imaging Core Facility of IFR114 of the University of Lille 2 for technical assistance, Julien Devassine and Delphine Cappe (Animal facility-IFR114) for the maintenance of transgenic mouse lines, the histology facility at University of Lille 2, André Défossez and Claude-Alain Maurage for the histological analyses of specimens, and Nathalie Jouy from the cytometry core facilities (Biolmaging Center Lille Nord de France-IFR114).

*J.P. and I.C. contributed equally to this work.

The authors declare no competing financial interests.

Correspondence should be addressed to Paolo Giacobini, Inserm U837, Jean-Pierre Aubert Research Center, Unit 837, Development and Plasticity of the Postnatal Brain, Place de Verdun, 59045, Lille Cedex, France. E-mail: paolo.giacobini@inserm.fr.

DOI:10.1523/JNEUROSCI.3057-12.2012

Copyright $\odot 2012$ the authors $\quad 0270-6474 / 12 / 3216992-11 \$ 15.00 / 0$
}

During the last 20 years, many molecular pathways that guide $\mathrm{GnRH}$ migration have been identified. However, only a few factors, including fibroblast growth factor-2 (Gibson et al., 2000; Tsai et al., 2005; Gill and Tsai, 2006), brain-derived neurotrophic factor (Cronin et al., 2004), and kisspeptin (Fiorini and Jasoni, 2010) are known to affect $\mathrm{GnRH}$ axon or neurite growth in vitro and/or in vivo. Secreted signaling molecules as well as extracellular matrix (ECM) proteins control the activity of cell-surface receptors that regulate the interactions of $\mathrm{GnRH}$ cells with each other, with the olfactory axonal scaffold, and with environmental cues (Wray, 2010). The integrins are a family of heterodimeric transmembrane receptors consisting of an $\alpha$ - and $\beta$-subunit, which mediate interactions between cells as well as between cells and the ECM (Reichardt and Tomaselli, 1991; Hynes, 2002). During brain development, integrins are involved in migration, axonal guidance, synaptogenesis, and peripheral nerve regeneration (Pasterkamp et al., 2003; Brakebusch and Fässler, 2005; Gardiner et al., 2005, 2007; Cingolani and Goda, 2008; Plantman et al., 2008; Moser et al., 2009).

The $\beta 1$-subunit-containing integrins ( $\beta 1$-integrin) represent the largest subgroup of integrins (Brakebusch and Fässler, 2005). GnRH neurons express $\beta 1$-integrin throughout their development and Semaphorin 7A signals through this cell-surface protein to regulate GnRH cell migration (Messina et al., 2011). Null mutation of the $\beta 1$-integrin gene in vivo has been achieved in mice and results in embryonic lethality (Fässler and Meyer, 1995; Stephens et al., 1995). The experiments in this paper study the effect of $\beta 1$-integrin on development of the GnRH system and reproduction by generating mice lacking this gene in $\mathrm{GnRH}$ neu- 
rons using the Cre/LoxP binary recombination system (Hamilton and Abremski, 1984; Singh et al., 2009). The absence of $\beta 1$-integrin altered migration of $\mathrm{GnRH}$ neurons and targeting of their axons to the ME, resulting in suboptimal maturation of the $\mathrm{GnRH}$ system in the adult brain. Examination of fertility revealed that lack of $\beta 1$-integrin in GnRH neurons caused delayed pubertal onset and disruption of estrous cyclicity in female GnRHItgb $1^{-/-}$mice, greatly impairing reproduction. These results demonstrate a critical role for $\beta 1$-integrin in $\mathrm{GnRH}$ neuronal function and mammalian reproduction.

\section{Materials and Methods}

Generation of GnRH neuron-specific $\beta 1$-integrin (Itgb1) conditional KO mice. GnRH::Cre mice (Yoon et al., 2005) were kindly provided by Dr. Catherine Dulac (Howard Hughes Medical Institute, Cambridge MA). Itg $b 1^{\text {loxP/loxP }}$ mice, in which exon 3 of $\beta 1$-integrin is flanked by loxP sites, were purchased from The Jackson Laboratory, maintained on a controlled $12 \mathrm{~h}$ dark/light cycle, provided with food and water ad libitum, and genotyped as described earlier (Stephens et al., 1995). The GnRH::Cre; Itgbl ${ }^{\text {loxP/loxP }}$ mice, designated as GnRH-Itgb $1^{-1-}$ mice, were generated by first mating female GnRH::Cre with male Itg $b 1$ loxP/loxP mice and then crossing a heterozygous (GnRH::Cre; Itgb1 $1^{\text {loxP/+ }}$ ) female with a heterozygous male to generate six genotype combinations. GnRH::Cre; Itgbl ${ }^{\text {loxP/loxP }}$ mice represent the homozygous conditional KO mice. GnRH::Cre; Itgb1 ${ }^{+/+}\left(\mathrm{GnRH}-\mathrm{Itgb} 1^{+/+}\right)$littermates were used as controls for all studies. All the transgenic lines were bred in our laboratory on a C57BL/6J;129sv background.

Generation of GnRH::Cre;Itgb1 ${ }^{\text {loxP/loxP }}$; GnRH::GFP triple transgenic mice. GnRH::GFP mice (Spergel et al., 1999) were kindly provided by Dr. Daniel J. Spergel (Section of Endocrinology, Department of Medicine, University of Chicago, Illinois). GnRH-Itgb $1^{-1-}$ mice were first crossed with $G n R H:: G F P$ animals to obtain triple heterozygous transgenic mice. Then a heterozygous (GnRH::Cre;Itgb1 ${ }^{\text {loxP/+ }} ;$ GnRH::GFP) female was crossed with a heterozygous male to generate all genotype combinations.

Genotyping and DNA extraction. For genotyping, three pairs of primers were used: GnRH-Cre-specific primers, sense $5^{\prime}$-CTGGTG TAGCTG ATGATCCG-3' , and antisense 5' -ATG GCT AAT CGC CAT CTT CC$3^{\prime}$; and Itgb $1^{\text {loxP/loxP }}$ primers, sense $5^{\prime}$-CGGCTCAAAGCAGAGTGTCAG TC-3', and antisense 5'-CCACAACTTTCCCAG TTA GCT CTC- $3^{\prime}$. GnRH-GFP mice were selected by PCR analysis of mouse tail DNA with primer GnRH 51 5'-GAAGTACTCAACCTACCAACGGAAG-3' and antisense primer hGFP1 5'-GCCATCCAGTTCCACGAGAATTGG-3', which amplified a 278 bp DNA fragment in mice transgenic for the GnRH-GFP minigene.

To obtain the genomic DNA of pups, a clipping from the ear or tail was collected and placed in 10\% Chelex-100 resin (Bio-Rad) with $0.1 \%$ Tween 20 and $0.15 \mathrm{mg} / \mathrm{ml}$ proteinase K. Samples were incubated at $50^{\circ} \mathrm{C}$ for $90 \mathrm{~min}$, proteinase $\mathrm{K}$ was inactivated at $95^{\circ} \mathrm{C}$ for $20 \mathrm{~min}$, and the solution was cooled to $10^{\circ} \mathrm{C}$. PCRs were performed using $7 \mu \mathrm{l}$ of DNA.

PCR was performed using a thermocycler ( 35 cycles: $30 \mathrm{~s}$ denaturation at $94^{\circ} \mathrm{C}, 1 \mathrm{~min}$ annealing at $58-65^{\circ} \mathrm{C}$, and 2 min elongation at $72^{\circ} \mathrm{C}$ ).

Animals. Mice were housed in a room with controlled photoperiod $(12 \mathrm{~h} \mathrm{light} / \mathrm{dark})$ and temperature $\left(21-23^{\circ} \mathrm{C}\right)$ with food and water ad libitum, in the animal facility of the Jean-Pierre Aubert Research Center at the Lille 2 University School of Medicine, France. All experiments were performed in accordance with the guidelines for animal use specified by the European Communities Council Directive of November 24, 1986 (86/609/EEC), regarding mammalian research and in accordance with National Institutes of Health (NIH)-National Institute of Neurological Disorders and Stroke guidelines, and Institutional Animal Care and Use Committee approval.

For immunohistochemical analysis, embryos were obtained from timed-pregnant control or conditional $\beta 1$-integrin KO mice and anesthetized with an intraperitoneal injection of chloral hydrate $(8 \% ; 350$ $\mathrm{mg} / \mathrm{kg}$ ). Heads from the embryos were washed thoroughly in cold $0.1 \mathrm{M}$ PBS, fixed in fixative solution [ $4 \%$ paraformaldehyde (PFA), $0.2 \%$ picric acid in $0.1 \mathrm{M} \mathrm{PBS}, \mathrm{pH} 7.4$ ] for $6-8 \mathrm{~h}$ at $4^{\circ} \mathrm{C}$ and cryoprotected in $20 \%$ sucrose overnight at $4^{\circ} \mathrm{C}$. The following day, heads were embedded in
OCT embedding medium (Tissue-Tek), frozen on dry ice, and stored at $-80^{\circ} \mathrm{C}$ until sectioning. $\mathrm{P} 7$ pups and adult mice ( $3-5$ months old) were anesthetized with chloral hydrate $(400 \mathrm{mg} / \mathrm{kg}$, i.p.) and perfused transcardially with $10 \mathrm{ml}$ of saline, followed by $100 \mathrm{ml}$ of $4 \%$ PFA, pH7.4. Brains were removed and immersed in the same fixative for $2 \mathrm{~h}$ at $4^{\circ} \mathrm{C}$ and stored in $0.1 \mathrm{M}$ PBS until slicing. Free-floating coronal sections (35 $\mu \mathrm{m}$ thick) were cut on a vibratome (VT1000S; Leica) and processed for immunohistochemistry.

Fluorescence-activated cell-sorter analysis. Heterozygous GnRH::Cre; Itgbl $1^{\text {loxP/+ }} ;$ GnRH::GFP mutants were crossed to obtain in the same litter GnRH::Cre; Itgb1 ${ }^{+/+}$; GnRH::GFP, GnRH::Cre; Itgb1 $1^{\operatorname{loxP} /+}$; GnRH::GFP and GnRH::Cre; Itgbl loxP/loxP; GnRH::GFP. Embryos were harvested at E12.5 from timed-pregnant GnRH::Cre;Itgb $1^{\text {loxP/+ }} ;$ GnRH::GFP mice, previously anesthetized with an intraperitoneal injection of chloral hydrate $(8 \% ; 350 \mathrm{mg} / \mathrm{kg})$ and killed by cervical dislocation. Nasal regions were dissected from each embryo and dissociated using a papain-based dissociation protocol previously described (Maric et al., 2003). After dissociation, the cells were physically purified using an EPICS ALTRA flow cytometer (Beckman Coulter). Sorted GFP-positive cells (yield: 600-800 cells obtained from each E12.5 embryo of the litter) were collected into a tube containing $500 \mu \mathrm{l}$ of sterile HBSS (Invitrogen) and subsequently centrifuged for $1 \mathrm{~min}$ at $7500 \mathrm{~g}$ (maximum) to relocate material to the bottom of the tube. HBSS was then aspired and $8 \mu \mathrm{l}$ of a solution containing $1 \mu \mathrm{l}$ of $0.1 \%$ Triton X-100 and $7 \mu \mathrm{l}$ of Prime RNase inhibitor (diluted 1:100 in diethylpyrocarbonate-treated water; Invitrogen) was added. Captured cells were used to synthesize first-strand cDNA using the SuperScript III First-Strand Synthesis System for reverse transcription (RT)-PCR (Invitrogen) following the manufacturer's instructions. Controls without reverse transcriptase were performed to demonstrate the absence of contaminating genomic DNA. RNAs isolated from heads of E12.5 embryos and GT1-7 cells were also reverse transcribed and used as positive controls. Total RNA from GT1-7 cells and E12.5 heads was isolated by extraction with TRIzol (Invitrogen).

The genotype of embryos was verified after fluorescenceactivated cell sorting (FACS) isolation and cDNAs of GnRH-GFP neurons isolated either from GnRH::Cre; Itgb $1^{+/+} ; G n R H:: G F P$ or GnRH::Cre; Itgbl ${ }^{\text {loxP/loxP}}$; GnRH::GFP embryos $(n=5$ for each genotype) were used for the PCR analysis. PCR was performed for $\mathrm{GnRH}$ and Itgb1 at 35 cycles on a thermocycler $\left(30 \mathrm{~s}\right.$ denaturation at $94^{\circ} \mathrm{C}, 30 \mathrm{~s}$ annealing at $55-65^{\circ} \mathrm{C}$, and 2 min elongation at $72^{\circ} \mathrm{C}$ ). PCR primer pairs were as follows: $\mathrm{GnRH}$ forward primer, $5^{\prime}$-GCTAGGCAGACAGAAACT TGC-3'; GnRH reverse primer, 5' -GCATCTACATCTTCTTCTGCC-3'; L19 (ribosomal housekeeping gene) forward primer, $5^{\prime}$-CCTGAAGGT CAAAGGGAATGTGTTC-3' and reverse primer, 5' -GGACAGAGTCTT GATGATCTCCTCC-3'; Itgb3 forward primer, 5'-AGGCTTGTGGTG CTTGGGCG-3'; and Itgb3 reverse primer, 5'-GGAGGTGGGGAGGGT GTCAGG- $3^{\prime}$. Itgb 1 primers were designed in exon 3 of $\beta 1$-integrin gene, which is floxed in conditional mutant mice when Cre recombination takes place. PCR primer pairs were as follows: Itgb 1 forward primer, 5' -GCAGGGCCAAATTGTGGGTGGT-3' and Itgb1 reverse primer, 5' GGCCGGAGCTTCTCTGCCAT-3'.

Ovarian histology and quantitative analysis. Ovaries were collected from 3-month-old control and conditional KO mice, fixed in 4\% PFA solution and stored at $4^{\circ} \mathrm{C}$. Paraffin-embedded ovaries were sectioned at a thickness of $5 \mu \mathrm{m}$ (histology facility, University of Lille 2, France) and stained using hematoxylin-eosin protocol. The number of corpora lutea, Graafian follicles, and atretic follicles were counted on photomicrographs from every tenth section throughout the ovary and statistical analysis was performed as described below.

Estrous cyclicity. To examine the possible effects of mutations on estrous cyclicity, vaginal lavage of female GnRH::Cre; Itgb $1^{\text {loxP/loxP }}$ mice and their control littermates $\left(\mathrm{GnRH}:: \mathrm{Cre}\right.$; Itgb1 $\left.{ }^{+/+}\right)$was performed every day (10:00 A.M. to 1:00 P.M.) using 0.9\% saline. Smears were observed under the microscope and the phase identified as diestrus (M/D) if they predominantly contained leukocytes, as proestrus $(\mathrm{P})$ if they predominantly contained basal and cornified nucleated cells, and as estrous (E) if they predominantly contained cornified epithelial cells. An estrous cycle was considered normal when the vaginal lavage had leukocytes for $2 \mathrm{~d}$ followed by $1 \mathrm{~d}$ of nucleated and $1-2 \mathrm{~d}$ of cornified cells. 
Gonadal steroid-induced LH surge protocol in ovariectomized animals. Mice were bilaterally ovariectomized (OVX) and implanted subcutaneously with SILASTIC capsules containing $17 \beta$-estradiol (E2; $1 \mu \mathrm{g} / 20 \mathrm{~g}$ body weight). SILASTIC capsules were prepared as follows: crystalline E2 was dissolved in absolute ethanol, mixed with SILASTIC medical adhesive (Type A) (Dow Corning) at a concentration of $0.1 \mathrm{mg} / \mathrm{ml}$ adhesive, and injected into SILASTIC tubing (Dow Corning; internal diameter, 1 $\mathrm{mm}$; external diameter, $2.125 \mathrm{~mm}$ ) (Bronson, 1981; Clarkson et al., 2008). Six days after OVX, mice received a single subcutaneous injection of $17 \beta$-estradiol 3-benzoate ( $1 \mu \mathrm{g} / 20 \mathrm{~g}$ of body weight in sesame oil) at 9:00 A.M. On the following day, animals received another subcutaneous injection of progesterone $(500 \mu \mathrm{g} / 20 \mathrm{~g}$ body weight in sesame oil $)$ at 9:00 A.M. Between 7:30 and 8:30 P.M. (lights off at 8:00 P.M.) on the same day, mice were anesthetized with an overdose of chloral hydrate $(400$ $\mathrm{mg} / \mathrm{kg}$, i.p.) and trunk blood was collected for LH assay. Trunk blood was collected in tubes containing EDTA $(0.2 \mathrm{M})$ and centrifuged at $6500 \mathrm{rpm}$ for $15 \mathrm{~min}$ at $4^{\circ} \mathrm{C}$ and the supernatant-obtained (plasma) was stored at $-80^{\circ} \mathrm{C}$ until ELISA for LH.

LH assay. Plasma LH was measured using Rodent LH ELISA kit (ERKR7010-A; Endocrine Technologies) with a sensitivity of $0.3 \mathrm{ng} / \mathrm{ml}$ and $7 \%$ intra-assay and $10 \%$ interassay coefficients of variation.

Immunohistochemistry. Tissues were cryosectioned (Leica cryostat) at $16 \mu \mathrm{m}$ for embryos, and at $35 \mu \mathrm{m}$ for free-floating sections for adult brains. Immunohistochemistry was performed as previously reported (Giacobini et al., 2008), using Alexa-Fluor 488-conjugated (1:400) and Cy3-conjugated (1:800) secondary antibodies (Invitrogen). Fluorescent specimens were mounted using 1,4-diazabicyclo[2.2.2] octane (SigmaAldrich). The primary antisera used were as follows: rabbit anti-GnRH (1:3000), a generous gift from Prof. G. Tramu (Centre Nationale de la Recherche Scientifique, URA 339, Université Bordeaux I, Talence, France) (Beauvillain and Tramu, 1980) and rat anti- $\beta 1$-integrin (1: 500; BD 558741).

Image analysis. Images were captured using a Nikon microscope (Eclipse $80 \mathrm{i}$ ) and $2 \times / 0.06 \mathrm{NA}, 10 \times / 0.30 \mathrm{NA}$, and $20 \times / 0.50 \mathrm{NA}$ objectives (Nikon) equipped with a digital camera (CX 9000; MBF Bioscience). For observation coupled with confocal analysis, a laser-scanning Fluoview confocal system (IX70; Olympus) and $10 \times / 0.30 \mathrm{NA}, 20 \times / 0.70$ $\mathrm{NA}$, and $60 \times / 1.25 \mathrm{NA}$ objectives (Olympus) were used. Subsequent analysis of digitized images was performed with Image (NIH, Bethesda, Maryland; http://imagej.nih.gov/ij/) and Photoshop (Adobe) software to process, adjust, and merge the photomontages.

Analysis of GnRH neurons in transgenic mice. Serial sagittal sections (16 $\mu \mathrm{m})$ from E14.5 GnRH-Itgb $1^{+/+}(n=4)$ and GnRH-Itgb1 ${ }^{-1-}(n=7)$ mice were cut and immunolabeled for $\mathrm{GnRH}$ throughout the head. Quantitative analysis of GnRH neuronal number, as a function of location, was performed over three regions (the nasal compartment, the nasal/forebrain junction, and ventral forebrain). Serial coronal sections (35 $\mu \mathrm{m})$ through the organum vasculosum of the lamina terminalis (OVLT) and ME of adult GnRH-Itgb $1^{+/+}$(females, $n=5$; males, $n=3$ ) and GnRH-Itgb1 ${ }^{-1-}$ (females, $n=5$; males, $n=4$ ) mouse brains were labeled for GnRH. Total number of GnRH cells was calculated for each brain (throughout the entire brain) and combined to give group means \pm SEM. No ectopic localization of GnRH neurons was detected in the brains of mutant mice, both during embryonic development as well as at the adult stage, compared with control animals, suggesting that the GnRH neurons were not misrouted.

The density of GnRH-immunoreactive terminals in the ME of control and GnRH-Itgb1 ${ }^{-/-}$mice was also evaluated. Two medial sections per animal ( $n=3$ each genotype) were chosen. Fiber intensity was evaluated with a confocal microscopy, Zeiss LSM 710. Images (24-bit) were collected with set parameters at $1.5 \mu \mathrm{m}$ intervals through a $35 \mu \mathrm{m}$ section using a $10 \times$ objective. Maximum intensity projections were calculated with ZEN 2009 (Carl Zeiss) algorithms for each series of confocal images that were binarized with ImageJ software (NIH; http://imagej.nih. gov/ij/). A user-defined threshold parameter was used and applied to each section to optimize detection of labeled fibers. The same threshold values were applied to all images to avoid subjective evaluation. The density values of labeled fibers were calculated based on the number of total pixels in each binarized image per area and combined to give group means \pm SEM.

Nasal explants. Embryos were obtained from timed-pregnant animals. Nasal pits of E11.5 NIH Swiss mice were isolated under aseptic conditions in Gey's Balanced Salt Solution (Invitrogen) enriched with glucose (Sigma-Aldrich) and maintained at $4^{\circ} \mathrm{C}$ until plating. Explants were placed onto glass coverslips coated with $10 \mu \mathrm{l}$ of chicken plasma (Cocalico Biologicals). Thrombin (10 $\mu$; Sigma-Aldrich) was then added to adhere (thrombin/plasma clot) the explant to the coverslip. Explants were maintained in defined serum-free medium (SFM) (Fueshko and Wray, 1994) containing $2.5 \mathrm{mg} / \mathrm{ml}$ Fungizone (Sigma-Aldrich) at $37^{\circ} \mathrm{C}$ with $5 \% \mathrm{CO}_{2}$ for up to $30 \mathrm{~d}$ in vitro (DIV). From culture day 3-6, fresh medium containing fluorodeoxyuridine $\left(8 \times 10^{-5} \mathrm{M}\right.$; Sigma-Aldrich $)$ was provided to inhibit the proliferation of dividing olfactory neurons and non-neuronal explant tissue. The medium was replaced with fresh SFM twice a week.

Functional assays in nasal explants. To determine the function of $\beta$-integrin on GnRH cell migration and axon outgrowth, pharmacological perturbation was performed on explants using Echistatin. Echistatin is a 49 aa protein with an Arg-Lys-Asp (RGD) sequence that is a member of the disintegrin family that occurs in the venom of Echis carinatus. It specifically inhibits $\beta 1$ - and $\beta 3$-integrins (Pfaff et al., 1994). Explants in experimental groups were maintained in SFM or SFM plus Echistatin $(0.1 \mu \mathrm{M})$ at 3 DIV for $72 \mathrm{~h}$. Drug concentrations were based on data from previous studies (Pasterkamp et al., 2003). Control explant medium was changed, as in the treatment group, at 3 and 6 DIV. At 7 DIV, explants were processed for immunocytochemistry for GnRH and density of the fibers in the periphery of the explants quantified. The main tissue mass contained the nasal pit/olfactory epithelial region, surrounding mesenchyme, and nasal midline cartilage. The periphery refers to the area surrounding the main tissue mass into which cells had spread and/or migrated.

Quantification of GnRH fiber density was performed on digitized photomicrographs (using a $20 \times$ UPlanFl Phase objective; Olympus I X50 inverted microscope equipped with a CCD CoolSNAP-Pro camera; Media Cybernetics). First, a threshold was manually set to specifically demonstrate the network structures in the image. The quality and resolution of the images allowed reliable and exclusive threshold of the networks without the need for image filtering. Images were then placed in bins and subjected to the "Skeletonize" function of ImageJ software, which excluded the GnRH cell somas from the analysis (see Fig. 4d,f), The corresponding density was measured by dividing the mean pixel area of GnRH fibers for the total area occupied by the fiber network. This quantitative method was chosen because the complex nature of the fiber network prevented the quantification of individual fiber length and branching. Three pictures were taken for each explant and average density was calculated for each sample to homogenize internal variability. Finally, mean density among treatment groups was calculated. Twelve animals were used for the control group $(n=12)$ and 7 for the treatment group (Echistatin; $n=7$ ).

The data are presented as means \pm SEM. All experiments used explants generated from different individuals on multiple culture dates.

Statistical analysis. For comparison of multiple groups, statistical significance was determined using a one-way ANOVA (for Gaussian distributed data) followed by Fisher 's least significant difference post hoc analysis test. For comparison between two groups, a two-tailed unpaired Student's $t$ test was used. The significance level was set at $p<0.05$. Data groups are indicated as mean \pm SEM.

\section{Results}

\section{Generation of conditional KO mice lacking $\beta 1$-integrin in GnRH neurons}

Recently it was shown that GnRH neurons begin expressing $\beta 1$-integrin at early stages of embryonic development and that Semaphorin 7A regulates the migration of immortalized $\mathrm{GnRH}$ cells through $\beta 1$-integrin activation (Messina et al., 2011). Interestingly, in the same work it has been shown that $\mathrm{GnRH}$ neurons expressed $\beta 1$-integrin at comparable levels in 
a

floxed Itgbl gene

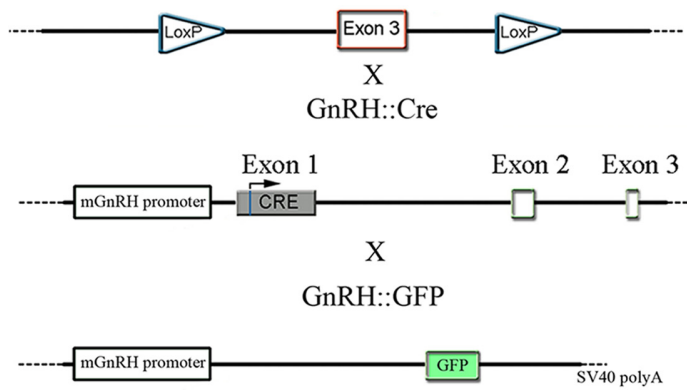

b
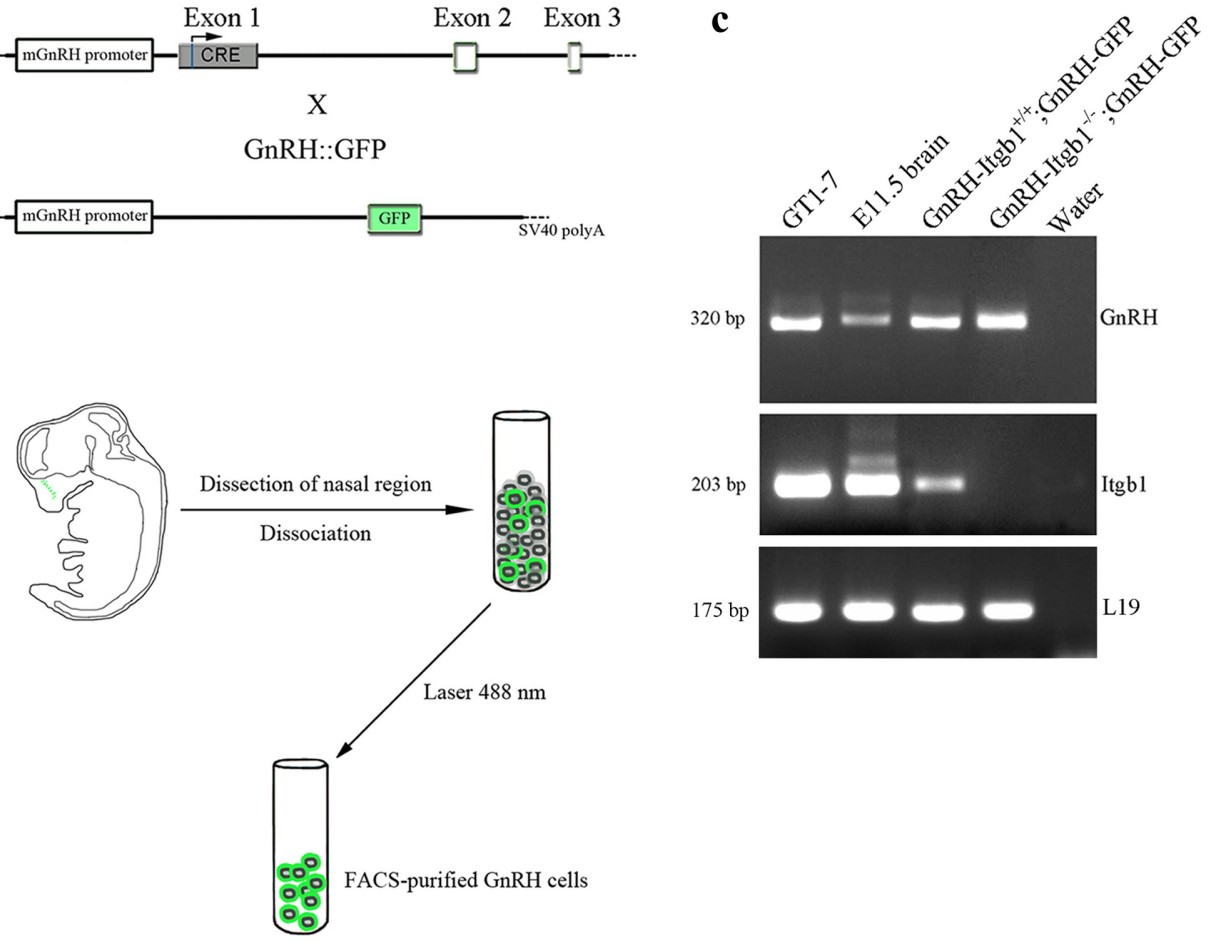

Figure 1. Generation of GnRH neuron-specific Itgb1 KO mouse. $a$, Exon 3 of the $\beta 1$-integrin gene (Itgb1) is flanked by two LoxP sites; (re recombinase expression is regulated by the mouse GnRH promoter. GnRH::Cre; Itgb 1 loxP/loxP mice were crossed with GnRH::GFP animals, which express the GFP under the control of the GnRH promoter, to generate triple-transgenic mice. $\boldsymbol{b}$, Schematic summarizing the steps of GnRH-GFP cells' isolation. E12.5 embryos were harvested from GnRH:: (re; Itgb $7^{\text {loxP/+ }}$; GnRH::GFP pregnant mice; the nasal regions were dissected and GnRH-GFP cells were purified by FACS. c, RT-PCR for GnRH and Itgb1 was performed on total RNA isolated from the indicated samples. Positive (GT1-7 cells; E11.5 whole heads) and negative controls (water) were included in the reaction mix.

the migratory and postmigratory stages, supporting the notion that this molecule might regulate several biological processes throughout development.

In the present work, the gene encoding the $\beta 1$-integrin subunit was inactivated in GnRH neurons by crossing floxed $\beta 1$-integrin (Itgb1) mice with LoxP sites flanking exon 3 (Jax mice; Fig. 1a) with GnRH::Cre mice (Yoon et al., 2005), which express the Cre recombinase gene in GnRH neurons, to obtain GnRH::Cre; Itgb1 ${ }^{+/+}\left(\mathrm{GnRH}-\mathrm{Itgb} 1^{+/+}\right)$and GnRH::Cre; Itgb1 ${ }^{\text {loxP/loxP }}$ $\left(\mathrm{GnRH}-\mathrm{Itgb1} 1^{-1-}\right)$ mice. Crosses typically displayed Mendelian segregation of the three embryonic genotypes: GnRH::Cre; Itgb1 loxP/loxP animals, which were homozygous null for the Itgbl gene in $\mathrm{GnRH}$ cells and wild type for this gene in other cell types; GnRH::Cre; Itgb $1^{\text {loxP/+ }}$ animals, which were heterozygous for the Itgbl gene in GnRH cells; and GnRH::Cre; Itg $b 1^{+/+}$which were wild type for Itgb1 in all cells, including GnRH cells. To confirm cell-specific deletion of Itgbl in GnRH cells, GnRH::Cre; Itgb $1^{\text {loxP/loxP }}$ animals were crossed with GnRH::GFP animals, which express the green fluorescent protein (GFP) under the control of the GnRH promoter (Spergel et al., 1999) so that reverse transcription (RT)-PCR analysis could be performed on embryonic GnRH-GFP cells isolated through fluorescence-activated cell sorting (FACS). E12.5 embryos were harvested from pregnant triple-mutant mice. At this stage, the majority of the GnRH population is located within the nasal region (Fig. 1b, green dots) (Schwanzel-Fukuda and Pfaff, 1989; Wray et al., 1989). There- fore, noses were dissected from mutant GnRH::Cre; Itgbl ${ }^{\text {loxP/loxP; }}$ GnRH::GFP (GnRH-Itgb1 ${ }^{-/-}$;GnRH-GFP) and control GnRH::Cre; Itgb1 $^{+/+}$;GnRH::GFP E12.5 embryos (GnRH-Itgb1 ${ }^{+/+}$; GnRHGFP) and purified GnRH-GFP-positive neurons were isolated by FACS (Fig. 1b). RT-PCR experiments were performed on cDNAs of primary GnRH-GFP neurons, positive controls (GT1-7 cells and E11.5 heads), and negative control cDNAs (water and -RT). Transcripts of the expected molecular size for mouse $G n R H$ and the housekeeping gene $L 19$ were found in all samples but negative control (Fig. 1c). Primers within the third exon of the Itgbl gene, which is floxed upon Cre recombination, were used. RT-PCR analysis revealed expression of $\operatorname{Itg} b 1$ in the positive samples and in the GnRH-Itgb $1^{+/+}$; GnRH-GFP cells, whereas Itgb1 was lacking in GnRH-Itgb ${ }^{-1-}$; GnRH-GFP neurons (Fig. 1c), confirming cell-specific deletion of Itgbl in GnRH neurons in conditional-KO mice.

\section{Lack of $\beta 1$-integrin expression in GnRH neurons leads to defects in their migratory process and their axonal targeting to the target tissues}

To investigate whether the absence of $\beta 1$-integrin signaling in GnRH neurons affects their development and migration, the number and distribution of $\mathrm{GnRH}$ neurons were examined at E14.5 in control (GnRH-Itgb1 ${ }^{+/+}$) and GnRH-Itgb1 ${ }^{-/-}$mice (Fig. $2 a-d$ ). The number of GnRH cells in the nasal compartment (cells located in the olfactory-vomeronasal epithelia and across 

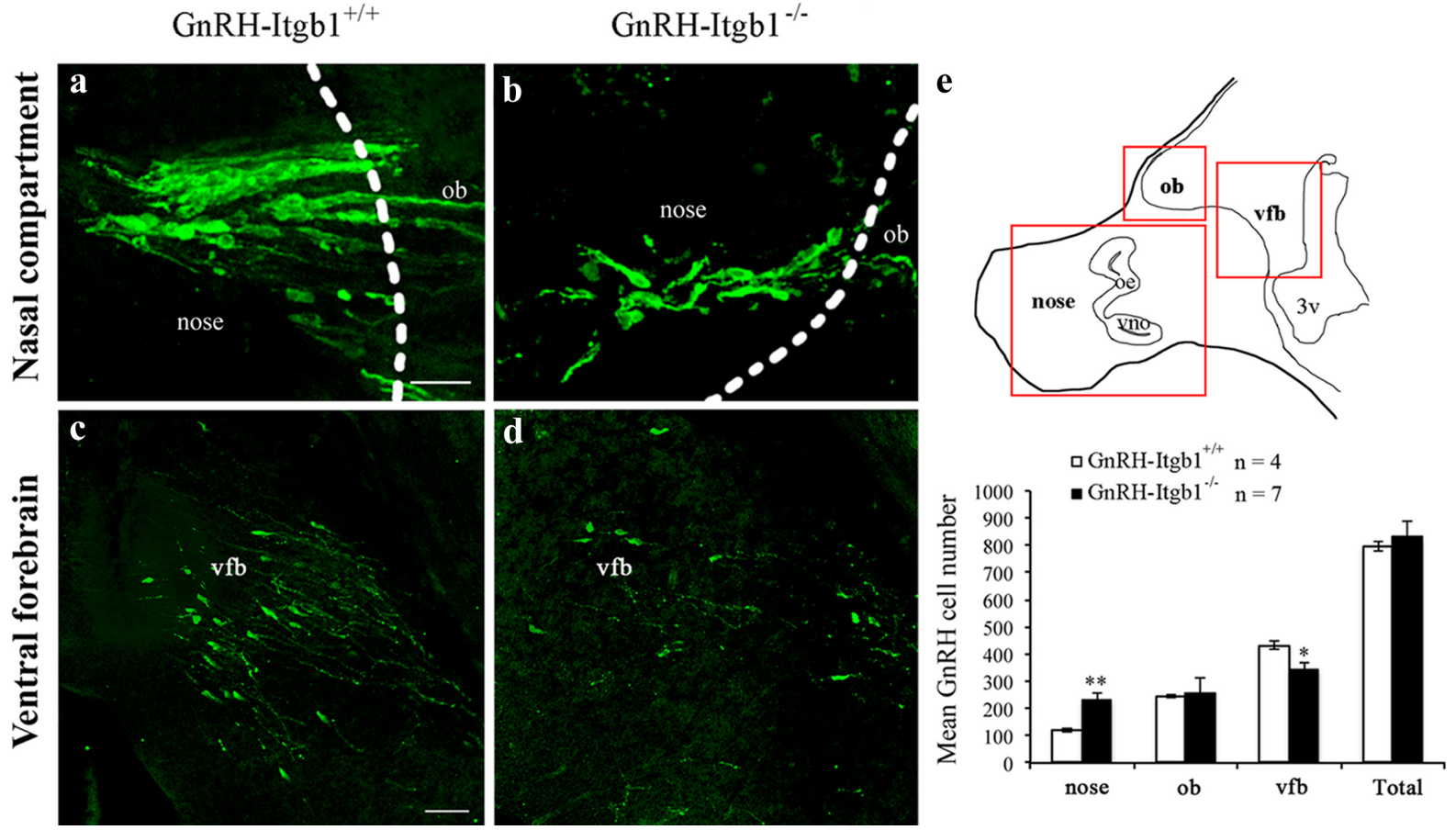

Figure 2. GnRH-Itgb ${ }^{-1-}$ mice show defective GnRH migration during embryonic development. $\boldsymbol{a}-\boldsymbol{d}$, Confocal photomicrographs showing GnRH immunoreactivity in sagittal sections of E14.5 control $(\boldsymbol{a}, \boldsymbol{c})$ and $\mathrm{GnRH}-\operatorname{ltgb} 1^{-/-}(\boldsymbol{b}, \boldsymbol{d})$ embryo heads. Dashed lines indicate the boundary between the nose and the forebrain. Analysis of the location of GnRH neurons in three regions along the migratory pathway, nasal compartment (nose), olfactory bulb (ob), and ventral forebrain (vfb) reveals a significant accumulation of cells in the nasal region of GnRH-Itgb $1^{-1-}$ mice when compared with control mice $(\boldsymbol{a}, \boldsymbol{b})$. Consistently, fewer GnRH neurons are located in the vfb of GnRH-Itgb $1^{-1-}$ than of GnRH-Itgb $1^{+/+}$embryos (c vs $\boldsymbol{d}$ ). $\boldsymbol{e}$, Top, Schematic of a sagittal section of an E14.5 embryo. Red boxes indicate the areas of the analysis of GnRH cell distribution. oe, Olfactory epithelium; vno, vomeronasal organ. Bottom, Quantitative analysis revealed a migratory defect of GnRH neurons at this developmental stage. Data are represented as means \pm SEM ( $n$, number of embryos; ${ }^{* *} p<0.005,{ }^{*} p<0.05$, Fisher 's least significant difference post hoc analysis). Scale bars: (in a) $\boldsymbol{a}, \boldsymbol{b}, 20 \mu \mathrm{m} ;$ (in c) $\boldsymbol{c}, \boldsymbol{d}, 40 \mu \mathrm{m}$.

the nasal mesenchyme), olfactory bulb (ob), and ventral forebrain (vfb) areas of embryos was determined (Fig. $2 e$, top, red boxes). GnRH-Itgb1 $1^{-/-}$animals showed a significant accumulation of GnRH cells in the nasal compartment compared with control littermates (Fig. 2e, bottom). Concomitantly, in mutant mice fewer $\mathrm{GnRH}$ neurons were located in the final brain target area (vfb; Fig. $2 c-e$ ), consistent with a migratory defect (one-way ANOVA, $\left.F_{(7,43)}=44.3, p<0.0001\right)$. To assess whether this defect was compensated after birth, the number and distribution of GnRH neurons were analyzed in brains of postnatal day 7 (P7) mice. Indeed, the total number of these neuroendocrine cells as well as their localization within the brain was unchanged between GnRH-Itgb $1^{-1-}$ and control infantile animals (GnRH-Itgb ${ }^{+/+}$ mice, $n=6$, mean GnRH cell number $=873 \pm 31$; GnRHItgb $^{-1-}$ mice, $n=4$, mean GnRH cell number $=829 \pm 52$; unpaired Student's $t$ test, $t_{(8)}=-0.768, p=0.46$ ).

However, in adult animals, a significant $30 \%$ reduction was found in the number of GnRH cell bodies (Fig. 3a,b) of GnRH$\mathrm{Itgb}^{-1-}$ mice compared with control littermates, regardless of the sex $\left(\mathrm{GnRH}-\mathrm{Itgb}^{+/+}, n=8\right.$, mean GnRH cell number $=$ $712 \pm 33$; GnRH-Itgb ${ }^{-1-}, n=9$, mean GnRH cell number $=$ $436 \pm 14$. $n$, number of mice; unpaired Student's $t$ test, $\left.t_{(15)}=7.98, p<0.0001\right)$. No differences in the number and bilateral distribution of $\mathrm{GnRH}$ neurons was observed between male and female brains of the same genotype (GnRH-Itgb ${ }^{+/+}$ females, $n=5$, mean GnRH cell number $=672 \pm 44$; GnRH$\mathrm{Itgb}^{+/+}$males, $n=3$, mean GnRH cell number $=780 \pm 15$; unpaired Student's $t$ test, $t_{(6)}=-1.81, p=0.12$; $\mathrm{GnRH}_{-} \mathrm{Itgb}^{-1-}$ females, $n=5$, mean GnRH cell number $=443 \pm 26$; GnRHItgb $^{-1-}$ males, $n=4$, mean GnRH cell number $=427 \pm 5$; unpaired Student's $t$ test, $t_{(7)}=0.52, p=0.62$ ).
Notably, the GnRH neurons of GnRH-Itgb1 ${ }^{-/-}$animals displayed shorter neurites than those of GnRH-Itgb ${ }^{+/+}$mice (Fig. $3 a, b$, insets). Consistent with this observation, densitometric analysis of immunostaining of the ME, the terminal field of $\mathrm{GnRH}$ neuroendocrine neurons, revealed a marked loss of $\mathrm{GnRH}$ fibers in homozygous mice when compared with control mice (Fig. $3 c, d$ ). The innervation of the ME of female GnRH-Itgb ${ }^{-/-}$ mice was reduced by $>70 \%$ when compared with control mice $\left(\mathrm{GnRH} \mathrm{Itgb}{ }^{+/+}, n=3\right.$, mean density of fibers $=409.8 \pm 97$; $\mathrm{GnRH}_{-} \mathrm{Itgb}^{-1-}, n=3$, mean density of fibers $=80.6 \pm 25$; unpaired Student's $t$ test, $\left.t_{(15)}=3.12, p<0.005\right)$. Quantitative analysis revealed a $33 \%$ reduction in the innervation of the ME in males $\left(\mathrm{GnRH}-\mathrm{Itgb}^{+/+}, n=3\right.$, mean density of fibers $=410 \pm 20$; $\mathrm{GnRH}^{-\mathrm{Itgb}^{-1-}}, n=4$, mean density of fibers $=271.3 \pm 12$; unpaired Student's $t$ test, $\left.t_{(5)}=6.43, p<0.005\right)$, thus evidencing a marked sex difference percentage reduction of fiber density in males vs females, $p<0.05$ )

\section{Inhibition of $\beta 1$-integrin in vitro disrupts $\mathrm{GnRH}$ fibers' network}

To determine the role of Itgbl in regulation of GnRH fiber elongation, a nasal explant model was used (Fig. 4a). Explants were treated with Echistatin $(0.1 \mu \mathrm{M})$, a selective inhibitor of $\beta 1$ - and $\beta 3$-integrins (Pfaff et al., 1994). RT-PCR experiments for $\beta 3$-integrin (Itgb3) were performed on cDNAs of primary E12.5 GnRH-GFP sorted neurons, GT1-7 cells, which display features of mature postmigratory GnRH neurons, and water (Fig. $4 b$ ). A transcript of the expected molecular size for the mouse Itgb3 was found in GT1-7 cells but not in primary migratory $\mathrm{GnRH}$ cells and in the negative control (Fig. 4b), indicating that 

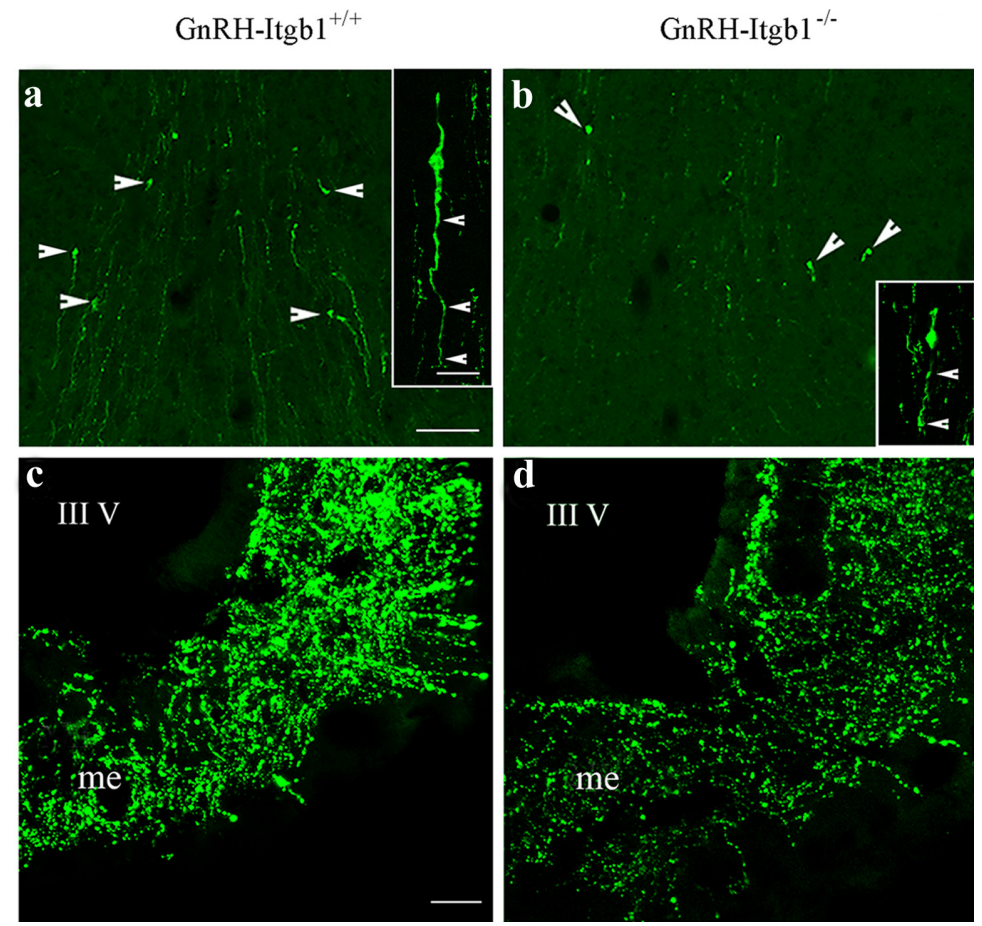

Figure 3. The lack of $\beta 1$-integrin in $\mathrm{GnRH}$ cells leads to a suboptimal number of $\mathrm{GnRH}$ neurons and reduced innervation of the median eminence (me) in adulthood. $\boldsymbol{a}-\boldsymbol{d}$, Confocal photomicrographs showing $\mathrm{GnRH}$ immunoreactivity in coronal sections of adult control $(\boldsymbol{a}, \boldsymbol{c})$ and conditional mutant $(\boldsymbol{b}, \boldsymbol{d})$ brains. Images show a significant reduction in the number of $\mathrm{GnRH}$ neurons at the level of the OVLT (arrowheads). In addition, $\beta 1$-integrin-KO GnRH neurons also display shorter neurites than control cells (insets in $\boldsymbol{a}$ and $\boldsymbol{b}$, arrowheads). $\boldsymbol{c}, \boldsymbol{d}$, The me shows a dramatic loss of GnRH-immunoreactive terminals in GnRH-Itgb1 ${ }^{-1-}$ mice (d) when compared with control littermates (c). III V, third ventricle. Scale bars: $\boldsymbol{a}$ and $\boldsymbol{b}$ and insets (in $\boldsymbol{a}$ ), 40 and $20 \mu \mathrm{m}$, respectively; $\boldsymbol{c}$ and $\boldsymbol{d}$ (in $\boldsymbol{c}$ ), $200 \mu \mathrm{m}$.

Echistatin could only act via Itgb1 signaling in GnRH cells in explants.

The application of Echistatin severely restricted the GnRH fiber network in the periphery of the explant (Fig. $4 c-f$ ). Quantitative analysis revealed a significant reduction in the density of the GnRH-immunoreactive fiber network following $\beta 1$-integrin blockage (controls, $n=12$, mean density of fibers $=0.057 \pm 0.005$; Echistatin-treated, $n=7$, mean density of fibers $=0.042 \pm 0.002)$. Data are combined values from three independent experiments ( $n$, number of explants; unpaired Student's $t$ test, $\left.t_{(17)}=3.06, p<0.05\right)$. The absence of a change in GnRH cell number after Echistatin treatment (control: $197 \pm 24, n=12$; Echistatin: $220 \pm 29, n=7$; unpaired Student's $t$ test, $\left.t_{(17)}=-0.72, p=0.48\right)$ indicates that this drug does not exert mitogenic or survival effects on GnRH neurons in vitro and is consistent with the hypothesis that $\beta 1$-integrin regulates neurite sprouting of primary $\mathrm{GnRH}$ neurons.

\section{GnRH::Cre;Itgb $1^{\operatorname{loxP} / \text { loxP }}$ female mice exhibit impaired fertility}

The observation that GnRH-Itgb $1^{-1-}$ mice had a dramatic loss of GnRH innervation in the ME suggested that fertility could be disrupted. Since alterations in neuroendocrine activity are expected to result in impaired reproductive capacity, fertility was examined in control and conditional Itgb1 KO mice using a continuous mating protocol for $90 \mathrm{~d}$. Male reproductive capacity was assessed by breeding young adult (P90) GnRH-Itgb1 ${ }^{-/-}$males with confirmed control dams $\left(\mathrm{GnRH}-\mathrm{Itgb} 1^{+/+}\right)$and monitoring the occurrence of litters over 3 months. In adult males, all fertility parameters examined, such as (1) number of days required to produce one litter (unpaired Student's $t$ test, $t_{(7)}=0.4, p=0.7$, (2) fertility index (number of litters/ month) (unpaired Student's $t$ test, $t_{(13)}=$ $0.26, p=0.79$ ), and (3) number of pups/ litter, did not differ between control and GnRH-Itgb $1^{-1-}$ mice (Fig. 5a-c; unpaired Student's $t$ test, $t_{(56)}=0.63, p=$ 0.53). In contrast, female GnRHItgb $1^{-/-}$mice showed significant alterations of the reproductive axis. Both the fertility index (one-way ANOVA, $F_{(2,18)}$ $=4.09, p=0.04)$ and the number of pups/litter (one-way ANOVA, $F_{(2,66)}=$ $5.94, p=0.004)$, were significantly reduced in the GnRH-Itgb ${ }^{-1-}$ females (Fig. $5 a-c$ ). Whereas, the latency to first pregnancy was not affected in any group analyzed (one-way ANOVA, $F_{(2,16)}=$ $0.12, p=0.9)$.

To determine whether the observed defects were associated with an ovulation deficiency, ovarian morphology in 3- to 5-month-old control and GnRHItgb $1^{-1-}$ female mice was evaluated. In contrast to control mouse ovaries, which contained large Graafian follicles and several corpora lutea, histological inspection of adult conditional null mouse ovaries revealed a significant reduction in the number of corpora lutea (unpaired Student's $t$ test, $t_{(8)}=3.1, p=$ 0.01 ), which serves as a confirmation that there are reduced numbers of ovulations (Fig. $5 d$,e).

\section{GnRH::Cre;Itgb $1^{\text {loxP/loxP }}$ female mice exhibit delayed puberty} and abnormal estrous cycles

Since the lack of $\beta 1$-integrin in GnRH neurons impacted only the reproductive axis in females and not in males, female mice were further characterized. Vaginal opening and first estrus have been shown to be estrogen-dependent processes, which correlate with the onset of puberty in rodents (Ojeda and Skinner, 2006). Thus, weaned GnRH-Itgb $1^{+/+}(n=12)$ and GnRH-Itgb $1^{-/-}(n=12)$ female littermates were examined for vaginal opening and first estrus. Vaginal opening was significantly delayed by $\sim 6 \mathrm{~d}$ in GnRH-Itgb $1^{-1-}$ female mice compared with control females (Fig. $6 a$; GnRH-Itgb $1^{+/+}: 29.1 \mathrm{~d} \pm 0.23$, GnRH-Itgb $1^{-1-}: 35.4 \mathrm{~d} \pm$ 0.57 ; unpaired Student's $t$ test, $\left.t_{(22)}=-10.3, p<0.0001\right)$. Analysis of cumulative percentage of vaginal opening within the two groups revealed that whereas, in control females, $100 \%$ of the mice had vaginal opening by P28, the entire population of GnRH-Itgb1 ${ }^{-1-}$ displayed vaginal opening at P37 (Fig. 6b). Similarly, the first estrus was significantly delayed by $\sim 10 \mathrm{~d}$ in GnRH-Itgb $1^{-/-}$versus GnRH-Itgb $1^{+/+}$mice (Fig. $6 a, c$; GnRHItgb $1^{+/+}: 32.5 \mathrm{~d} \pm 0.23$, GnRH-Itgb $1^{-1-}: 41.9 \mathrm{~d} \pm 0.58$; unpaired Student's $t$ test, $\left.t_{(22)}=-15, p<0.0001\right)$. Daily inspection of vaginal cytology in GnRH-Itgb1 ${ }^{-1-}$ mice revealed absence of normal estrous cyclicity (Fig. 7a). GnRH-Itgb $1^{-1-}$ mice exhibited a persistent diestrus state $\left(\mathrm{GnRH}-\mathrm{Itgb} \mathrm{1}^{+/+}\right.$mean percentage time in proestrus: $14 \pm 2$, GnRH-Itgb $1^{-1-}$ mean percentage time in proestrus: $1 \pm 0.7$, unpaired Student's $t$ test, $t_{(22)}=7, p<0.0001$; GnRH-Itgb ${ }^{+/+}$mean percentage time in 
a

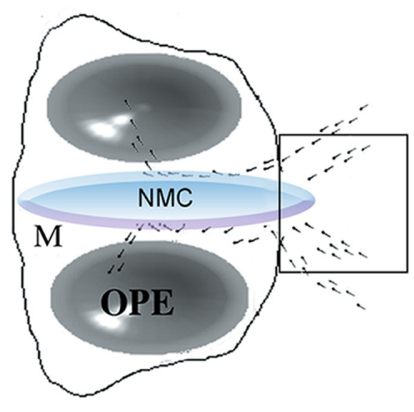

b

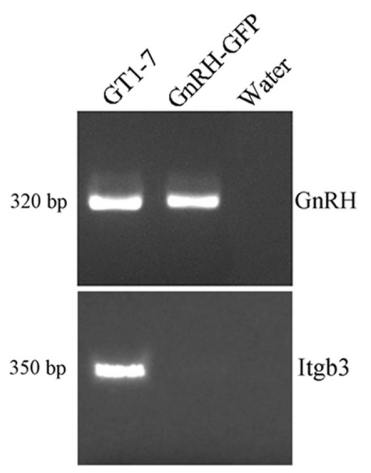

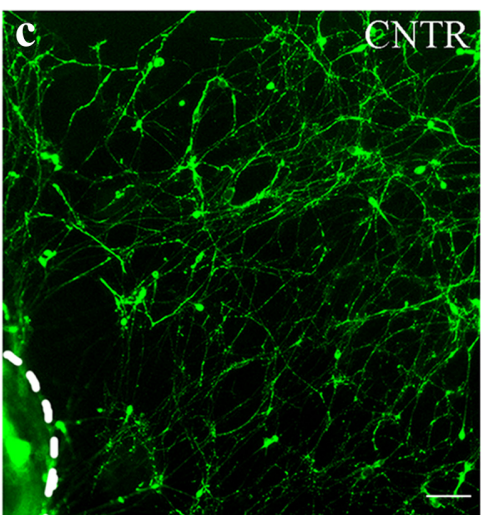
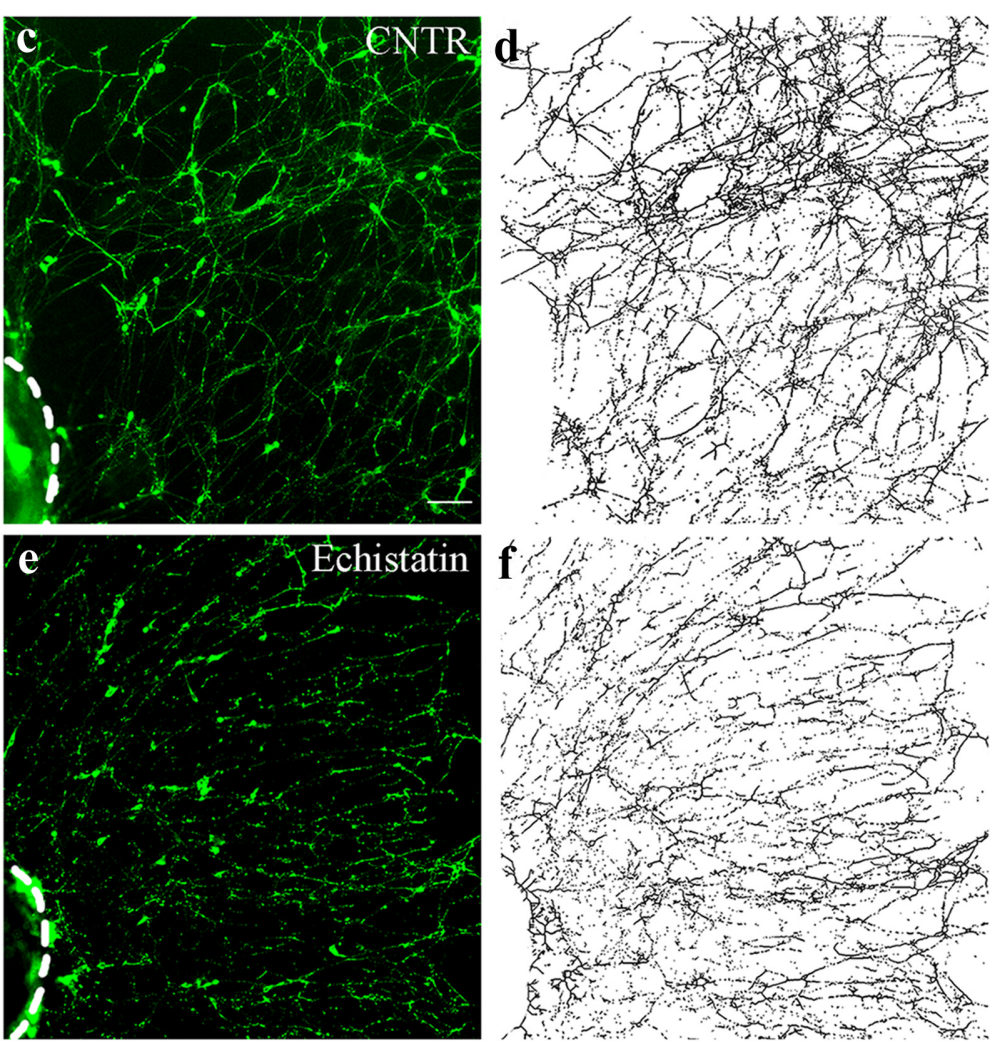

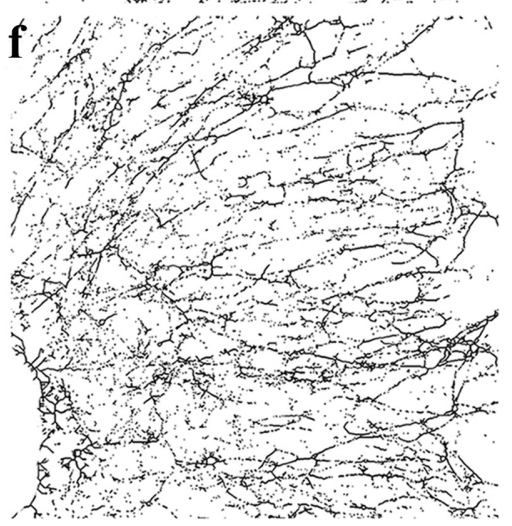

Figure 4. $\quad \beta 1$-integrin inhibition disrupts GnRH fibers network in vitro. $\boldsymbol{a}$, Schematic of a nasal explant removed from an E11.5 mouse and maintained in serum-free media for 7 DIV. Ovals represent olfactory pit epithelium (OPE); in center is nasal midline cartilage (NMC) and surrounding mesenchyme (M). GnRH neurons (dots) migrate from OPE and follow olfactory axons to the midline and off the explant into the periphery. Boxed region within schematic is area shown in $\mathbf{c}-\boldsymbol{f}$. $\boldsymbol{b}$, Representative gel of $\mathrm{PCR}$ products for $\mathrm{GnRH}$ and $\beta 3$-integrin (Itgb3) from $\mathrm{GnRH}$ neurons isolated from GnRH::GFP E12.5 nasal regions through FACS. Positive (GT1-7 cells) and negative controls (water) were included in the reaction mix. $c$, $e$, Explants in experimental groups were maintained in SFM (CNTR) with or without Echistatin ( $0.1 \mathrm{~mm})$ at 3 DIV for $72 \mathrm{~h}$ and fixed at 7 DIV for immunocytochemical processing (GnRH, green). $\boldsymbol{d}, \boldsymbol{f}$, Representative images binarized and subjected to the "Skeletonize" function of ImageJ software. Scale bars: (in c) $\mathbf{c}-\mathbf{f}, 40 \mu \mathrm{m}$.

estrus: $26.5 \pm 2$, GnRH-Itgb $1^{-1-}$ mean percentage time in diestrus: $10.5 \pm 1$, unpaired Student's $t$ test, $t_{(22)}=7, p<0.0001$; GnRH-Itgb $1^{+/+}$mean percentage time in diestrus: $59 \pm 1$, GnRH-Itgb $1^{-1-}$ mean percentage time in diestrus: $88 \pm 1$; unpaired Student's $t$ test, $\left.t_{(22)}=-15, p<0.0001\right)$ with the sporadic occurrence of complete $4-5 \mathrm{~d}$ ovarian cycles (Fig. $7 c$ ), whereas control littermates showed regular estrous cyclicity (Fig. 7a,b). These findings show that GnRH-Itgb ${ }^{-/-}$mice display ovarian cyclicity deficits.

\section{GnRH::Cre;Itgb1 ${ }^{\text {loxP/loxP }}$ mice do not elevate $\mathrm{LH}$ under gonadal steroid-positive feedback condition}

In female mice, GnRH-induced LH surge stimulates ovulation, which is an essential process in fertility and is induced by positive feedback of gonadal steroids on the hypothalamic-pituitary axis. To examine the GnRH/LH surge, an OVX-E-P replacement model was used as previously described (Hanchate et al., 2012). While OVX GnRH-Itgb ${ }^{+/+}$mice exhibited an LH surge in response to gonadal steroid treatment (Fig. 8; unpaired Student's $t$ test, $\left.t_{(6)}=-198, p<0.0001\right)$, OVX GnRH-Itgb1 ${ }^{-/-}$littermates did not exhibit an LH surge, displaying levels of LH that were near the limit of detection (Fig. 8; unpaired Student's $t$ test, $t_{(8)}=0.67$, $p=0.52)$.

\section{Discussion}

Integrins are heterodimeric $(\alpha \beta)$ ECM receptors that are widely expressed throughout the mammalian nervous system (Pinkstaff et al., 1999), where they regulate development and function of neurons (Anton et al., 1999; Benson et al., 2000; Chavis and Westbrook, 2001; Graus-Porta et al., 2001; Huang et al., 2006; Belvindrah et al., 2007; Webb et al., 2007). Using a novel mouse model of $\beta 1$-integrin ablation in GnRH neurons we uncovered a fundamental role of integrins in the development of the $\mathrm{GnRH}$ system, establishment of the hypothalamic-pituitary-gonadal axis and involvement of $\beta 1$-integrin signaling in the initiation of puberty and regulation of the pre-ovulatory gonadotropin surge.

RT-PCR analysis on GnRH-sorted cells deriving from triplemutant embryos (GnRH::Cre; Itgb1 ${ }^{\text {loxP/loxP }}$ GnRH::GFP) revealed that recombination has already occurred at E12.5, when the majority of this population is migrating across the nasal mesenchyme. Analysis of conditional mutant embryos at E14.5 shows deficits consistent with the reduced migration of $\mathrm{GnRH}$ neurons. However, this delay appears to be compensated during later developmental stages with the number and distribution of GnRH neurons being unaffected in the brain of P7 mutants compared with control mice. Indeed, many factors controlling the precise journey of these neuroendocrine cells from nose to brain have been elucidated (Wierman et al., 2011), which could be responsible for such compensatory mechanism.

Interestingly, the number of GnRH cells is significantly reduced by approximately a third in the brains of adult GnRHItgb $1^{-/-}$mice, implying that cell death might occur within this cell population between the infantile and the adult stage. Indeed, it is very well established that integrin-mediated signals are necessary in normal cells to control cell survival and apoptosis (via 
a
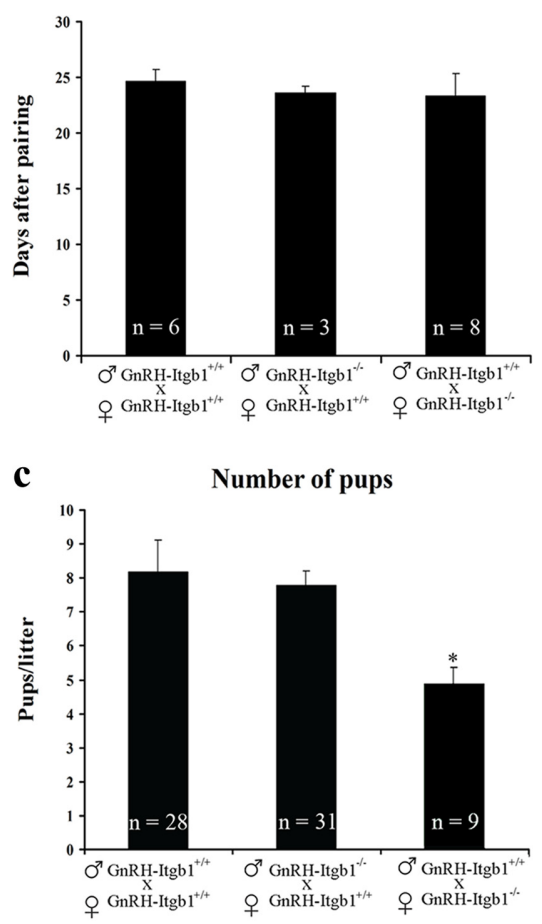

e

\begin{tabular}{lcc} 
& GnRH-Itgbl $^{+/+}$ & GnRH-Itgbl $^{-/ *}$ \\
\hline Number of corpora lutea & $19.8 \pm 1.3$ & $15.0 \pm 2.8^{\mathrm{a}}$ \\
Number of Graafian follicles & $5.8 \pm 0.8$ & $4.8 \pm 1.6$ \\
Number of atretic follicles & $3.2 \pm 0.9$ & $5.8 \pm 0.8$ \\
\hline
\end{tabular}

All values were expressed as mean \pm SEM, $\mathrm{n}=5$

Unpaired Student's t-test: ${ }^{\text {a }} \mathrm{P}<0.05$

Figure 5. Female GnRH-Itgb $1^{-/-}$mice exhibit impaired fertility. Fertility in GnRH-Itgb $1^{+/+}$and GnRH-Itgb $1^{-/-}$female mice. Matings were performed for $90 \mathrm{~d}$. $\boldsymbol{a}$, The latency to first pregnancy was not affected in any group analyzed. $\boldsymbol{b}$, The total number of litters per female was significantly reduced in conditional mutant female mice compared with control females mated with either GnRH-Itgb $1^{-1-}$ or GnRH-Itgb ${ }^{+/+}$males. c, Conditional mutant female mice gave birth to a reduced number of pups per litter compared with control females. Data are represented as means \pm SEM ( $n$, number of animals; ${ }^{*} p<0.01$, Fisher's least significant difference post hoc analysis). $\boldsymbol{d}$, Morphological analysis of ovaries from 3- to 5 -month-old control (GnRH-ltgb ${ }^{+/+}$; $n=5)$ and mutant mice (GnRH-Itgb1 $\left.{ }^{-1-} ; n=5\right)$. Ovary sections $(5 \mu \mathrm{m}$ thick) were stained with hematoxylin-eosin. In $\mathrm{GnRH}-\operatorname{ltgb} 1^{-1-}$ females, the ovaries displayed a greater number of atretic follicles (AF) and a relative paucity of corpora lutea (CL), when compared with the ovaries of control littermates in which follicular development was normal. GF, Graafian follicles. $\boldsymbol{e}$, The numbers of corpora lutea, Graafian follicles, and atretic follicles were quantified in the ovaries of CNTR and KO mice. Data are represented as means \pm SEM. ${ }^{\mathrm{a}} p<0.05$, unpaired Student's $t$ test. Scale bar, $100 \mu \mathrm{m}$.

PI3-kinase and Akt; Hynes, 2002). However, due to the small size of the GnRH neuronal population and the limited temporal window during which apoptosis takes place, it is not possible to determine whether this is the case. The loss of GnRH immunoreactive neurons has also been reported in other mutant mice, such as neuropilin $2^{-1-}$, netrin $1^{-1-}$, and ephrin $3-5^{-1-}$ mice, but its cause remains undetermined (Schwarting et al., 2004; Gamble et al., 2005; Cariboni et al., 2007).

At the end of the migratory process, GnRH neurons undergo striking structural plasticity, and elongate their axons to contact the ME. Previous studies have shown that many neurons use members of the integrin family of cell-surface receptors to respond to factors that promote neurite growth and axonal elongation to their final target areas (Hynes, 2002). Consistently, ablation of Itgb1 gene in GnRH neurons leads to defects in neuritogenesis. In fact, $\mathrm{GnRH}$-Itgb $1^{-/-}$animals display shorter neurites than those of GnRH-Itgb ${ }^{+/+}$mice. To verify that such defects were caused by the removal of $\beta 1$ integrin, perturbation of primary $\mathrm{GnRH}$ cells was performed in nasal explants. Indeed, inhibition of $\beta 1$-integrin significantly disrupted the GnRH fibers network in vitro, further substantiating the notion that integrins are required for the proper neurite outgrowth of these neuroendocrine cells.

The selective deletion of Itgb1 in $\mathrm{GnRH}$ neurons is also responsible for striking reproductive defects in female mice, as evidenced by the delay in the onset of puberty, alterations in ovarian morphology, and the reduced number and size of litters. GnRH-Itgb $1^{+/-}$female mice did not show any reproductive abnormalities (data not shown) indicating that one $\operatorname{Itg} b 1$ allele is sufficient to grant normal development of the GnRH axis.

A very interesting aspect of the present study is the finding that male reproductive function was not affected by the disruption of $\beta 1$-integrin signaling in $\mathrm{GnRH}$ neurons, as shown by the continuous mating experiments. Notably, both male and female GnRH-Itgb $1^{-/-}$mice have a comparable decrease in the size of the GnRH neuronal population within the brain when compared with control mice (30\% reduction). However, the extent of reduction in GnRH neuronal projections was sexually dimorphic, being milder in male than in female GnRH-Itgb $1^{-/-}$mice (33\% reduction in male versus $70 \%$ reduction in female mutant mice). Hormonal factors, such as sex steroids including estrogens and testosterone, direct formation of sexually dimorphic circuits by influencing axonal guidance and synaptogenesis, neurogenesis, cell migration, cell differentiation, and cell death (Simerly, 2002; Tobet et al., 2009). Several reports indicate that gonadal steroids are capable of modulating the expression of different classes of guidance molecules, which are known to bind $\beta 1$-integrin to activate their intracellular signaling pathway, in physiological as well as in pathological conditions (Cullinan-Bove and Koos, 1993; Liu et al., 1994; Nikolova et al., 1998; Pavelock et al., 2001; Khan et al., 2005; Nguyen et al., 2011; Richeri et al., 2011). Thus, it is possible that gonadal steroid-dependent mechanisms could be responsible of the sex difference observed in the $\mathrm{GnRH}$ neuronal projections to the ME in GnRH-Itgb $1^{-/-}$mice.

A strong precedent for this notable sex difference does exist since several gene mutations including cyclooxygenase (Lim et al., 1997), progesterone receptor (Lydon et al., 1996), ErbBs (Prevot et al., 2005), and FSH (Kumar et al., 1997) cause female infertility but have no effect on male reproductive capacity.

The phasic secretion of LH from the pituitary gland is perhaps the most significant sex difference in endocrine physiology ( $\mathrm{Si}$ merly, 1998). In female rats, plasma levels of estradiol increase during the estrous cycle and lead to a massive surge in LH secre- 
a

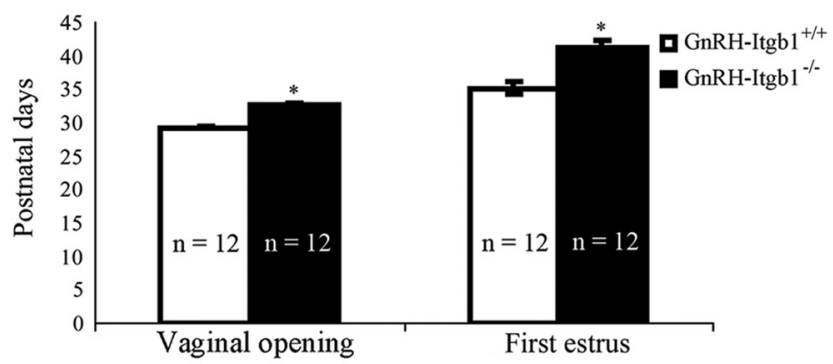

b

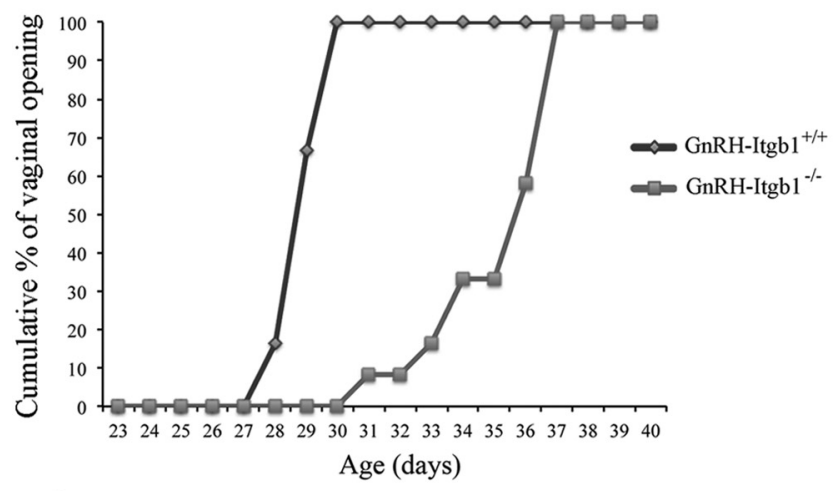

c

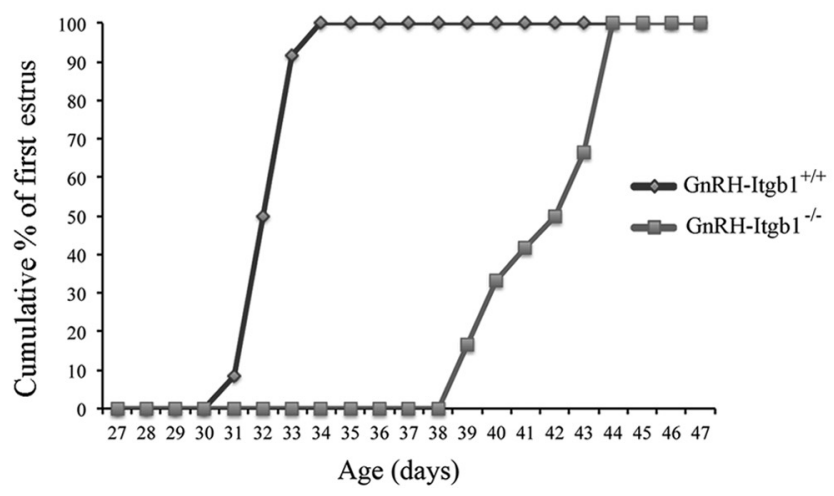

Figure 6. Female GnRH-ltgb1 ${ }^{-1-}$ mice exhibit delayed puberty and abnormal estrous cyclicity. $\boldsymbol{a}$, Vaginal opening and time of the first estrus were examined daily from P21 as good indicators of puberty onset in rodents. Vaginal opening in GnRH-Itgb $1^{-1-}$ females was delayed by $\sim 6 \mathrm{~d}$ when compared with control females. Vaginal smears were prepared daily following vaginal opening, and the age at first estrus (defined by the presence of a majority of cornified epithelial cells) was recorded ( $n=12$ each group). First estrus was delayed by $\sim 10 \mathrm{~d}$ in $\mathrm{GnRH}-\operatorname{ltgb} 1^{-1-}$ females. Data are represented as means \pm SEM. $n$, number of animals; ${ }^{*} p<0.0001$, unpaired Student's $t$ test. $\boldsymbol{b}$, Analysis of cumulative percentage of vaginal opening within the two groups. In control females, $100 \%$ of the mice displayed vaginal opening by the $\mathrm{P} 28$, whereas the entire population of $\mathrm{GnRH}-\operatorname{ltgb} 1^{-1-}$ mice had vaginal opening by the P37.c, Analysis of cumulative percentage of the first estrus within the two groups. In control females, $100 \%$ of the mice had the first estrus by the P34, whereas the entire population of GnRH$\operatorname{ltg} b 1^{-1-}$ mice entered puberty at the P44.

tion on the afternoon of proestrus (Simerly, 1998). Treatment of OVX adult female rats with exogenous estradiol causes afternoon surges in LH release, yet treatment of gonadectomized male rats fails to cause a similar response due to organizational effect of androgens around the time of birth (Jarzab and Döhler, 1984).

Gonadal steroids via positive feedback to the hypothalamicpituitary gonadotropic axis control the onset of the LH surge and thus ovulation. After exogenous administration of estradiol benzoate and progesterone to OVX GnRH-Itgb $1^{-/-}$females, GnRH neurons failed to induce an LH surge, suggesting that the repro- $\mathbf{a}$

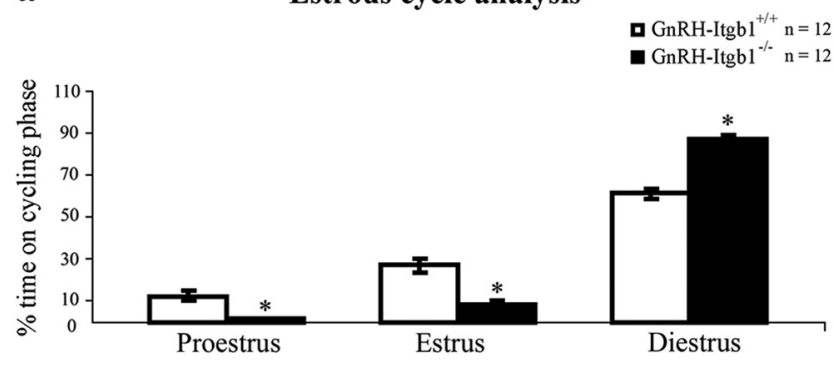

b

GnRH-Itgbi $^{+/+}$female mice cyclicity

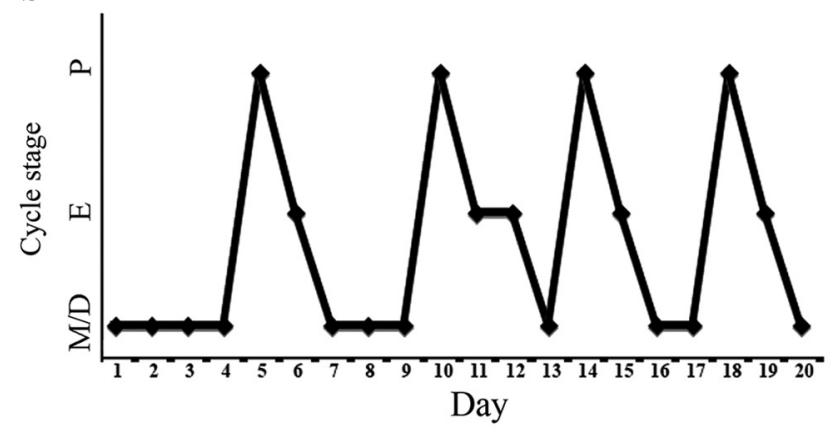

c

GnRH-Itgb1 $1^{-/-}$female mice cyclicity

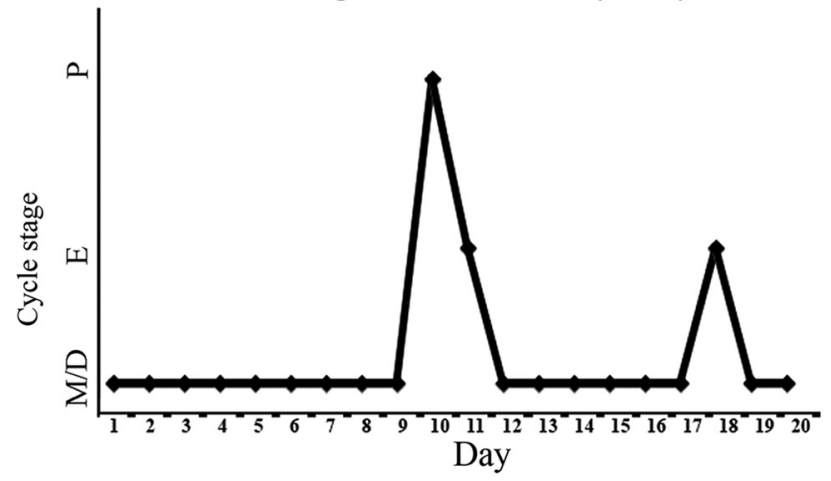

Figure 7. Female GnRH-Itgb1 ${ }^{-1-}$ mice show abnormal estrous cyclicity. Vaginal cytology was assessed for $20 \mathrm{din} \mathrm{GnRH}-\operatorname{ltgb} 1^{+/+}(n=12)$ and GnRH-Itgb $1^{-/-}$mice $(n=12) \cdot \boldsymbol{a}$, Time in each estrous cycle phase as a percentage of the cycle. GnRH-Itgb1 ${ }^{-/-}$females remained in a predominantly diestrus state with the sporadic occurrence of complete ovarian cycles, whereas control littermates showed a regular estrous cyclicity. Data are represented as means \pm SEM. $n$, number of animals; ${ }^{*} p<0.0001$, unpaired Student's $t$ test. M/D, metestrus/ diestrus; E, estrus; $P$, proestrus. $\boldsymbol{b}, \boldsymbol{c}$, Representative estrous cyclicity of control (b) and GnRH$\operatorname{ltgb} 1^{-1-}$ mice (c). Control females typically show a regular $4 \mathrm{~d}$ ovarian cycle $(\boldsymbol{b})$, whereas $\mathrm{GnRH}-\operatorname{ltgb} 1^{-1-}$ mice are characterized by with highly irregular cycles (c).

ductive dysfunction of these animals is due to an attenuated $\mathrm{GnRH}$-system function. We cannot exclude that additional defects affecting the development and function of synapses on $\mathrm{GnRH}$ dendrites could occur in the absence of $\beta 1$-integrin. Recent studies have demonstrated that the dendritic tree of $\mathrm{GnRH}$ neurons is subject to marked remodeling during postnatal development (Cottrell et al., 2006) and that the density of spines along $\mathrm{GnRH}$ dendrites increases not only during sexual maturation (Cottrell et al., 2006), but also at the onset of the GnRH/LH surge induced by gonadal steroids in OVX adult mice (Chan et al., 2011). Notably, previous works have demonstrated the essential role of integrins in synapse maturation and plasticity (Benson et al., 2000; Chavis and Westbrook, 2001; Huang et al., 2006; Webb et al., 2007; Warren et al., 2012). In addition to these functions, $\beta 1$-containing integrins have been also shown to influence circuit 


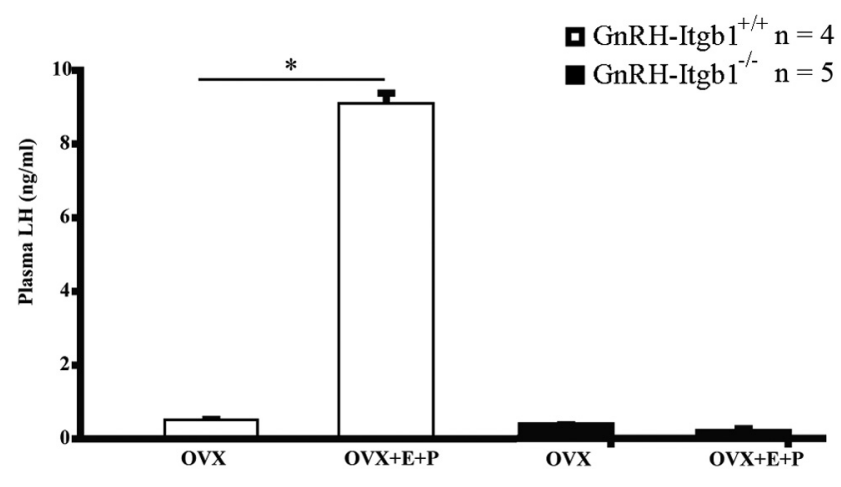

Figure 8. LH surge in $\mathrm{GnRH}-\operatorname{ltgb} 1^{-/-}$. Profile of $\mathrm{LH}$ surge in OVX mice of the two genotypes treated with estrogen and progesterone. Note that while control OVX mice $(n=4)$ exhibited an LH surge in response to gonadal steroid treatment, $\mathrm{GnRH}-\operatorname{ltgb} 1^{-1-}$ littermates $(n=5)$ did not, confirming that estrogen-based positive feedback is disrupted. Data are represented as means \pm SEM. $n$, number of animals; ${ }^{*} p<0.0001$, unpaired Student's $t$ test.

function by controlling dendritic arbor formation and/or stability. For instance, inhibiting $\beta 1$-integrin signaling in developing retinal ganglion cells blocks dendritic growth (Lilienbaum et al., 1995), and plating cortical neurons on integrin substrates such as laminin promotes dendritic branching and extension (Moresco et al., 2005).

Thus, the dysfunction of the GnRH system in $\beta 1$-integrin mutants likely derives from a combination of multiple developmental defects ultimately affecting neuronal activity and secretion of GnRH neurons.

This work demonstrates the critical role of GnRH Itgb1 in the complex developmental signaling pathways that control mammalian reproduction.

Future studies should determine which ligands activating $\beta 1$ integrin signaling cascade could be modulated by sexual hormones within the CNS and what effect they have on neuronal connectivity and function during critical periods of the GnRH network activation.

\section{References}

Anton ES, Kreidberg JA, Rakic P (1999) Distinct functions of alpha3 and alpha(v) integrin receptors in neuronal migration and laminar organization of the cerebral cortex. Neuron 22:277-289. CrossRef Medline

Beauvillain JC, Tramu G (1980) Immunocytochemical demonstration of LH-RH, somatostatin, and ACTH-like peptide in osmium-postfixed, resin-embedded median eminence. J Histochem Cytochem 28:10141017. CrossRef Medline

Belvindrah R, Hankel S, Walker J, Patton BL, Müller U (2007) Betal integrins control the formation of cell chains in the adult rostral migratory stream. J Neurosci 27:2704-2717. CrossRef Medline

Benson DL, Schnapp LM, Shapiro L, Huntley GW (2000) Making memories stick: cell-adhesion molecules in synaptic plasticity. Trends Cell Biol 10: 473-482. CrossRef Medline

Brakebusch C, Fässler R (2005) beta 1 integrin function in vivo: adhesion, migration and more. Cancer Metastasis Rev 24:403-411. CrossRef Medline

Bronson FH (1981) The regulation of luteinizing hormone secretion by estrogen: relationships among negative feedback, surge potential, and male stimulation in juvenile, peripubertal, and adult female mice. Endocrinology 108:506-516. CrossRef Medline

Cariboni A, Hickok J, Rakic S, Andrews W, Maggi R, Tischkau S, Parnavelas JG (2007) Neuropilins and their ligands are important in the migration of gonadotropin-releasing hormone neurons. J Neurosci 27:2387-2395. CrossRef Medline

Chan H, Prescott M, Ong Z, Herde MK, Herbison AE, Campbell RE (2011) Dendritic spine plasticity in gonadatropin-releasing hormone $(\mathrm{GnRH})$ neurons activated at the time of the preovulatory surge. Endocrinology 152:4906-4914. CrossRef Medline
Chavis P, Westbrook G (2001) Integrins mediate functional pre- and postsynaptic maturation at a hippocampal synapse. Nature 411:317-321. CrossRef Medline

Cingolani LA, Goda Y (2008) Differential involvement of beta3 integrin in pre- and postsynaptic forms of adaptation to chronic activity deprivation. Neuron Glia Biol 4:179-187. CrossRef Medline

Clarkson J, d'Anglemont de Tassigny X, Moreno AS, Colledge WH, Herbison AE (2008) Kisspeptin-GPR54 signaling is essential for preovulatory gonadotropin-releasing hormone neuron activation and the luteinizing hormone surge. J Neurosci 28:8691-8697. CrossRef Medline

Cottrell EC, Campbell RE, Han SK, Herbison AE (2006) Postnatal remodeling of dendritic structure and spine density in gonadotropin-releasing hormone neurons. Endocrinology 147:3652-3661. CrossRef Medline

Cronin AS, Horan TL, Spergel DJ, Brooks AN, Hastings MH, Ebling FJ (2004) Neurotrophic effects of BDNF on embryonic gonadotropinreleasing hormone $(\mathrm{GnRH})$ neurons. Eur J Neurosci 20:338-344. CrossRef Medline

Cullinan-Bove K, Koos RD (1993) Vascular endothelial growth factor/vascular permeability factor expression in the rat uterus: rapid stimulation by estrogen correlates with estrogen-induced increases in uterine capillary permeability and growth. Endocrinology 133:829-837. CrossRef Medline

Fässler R, Meyer M (1995) Consequences of lack of beta 1 integrin gene expression in mice. Genes Dev 9:1896-1908. CrossRef Medline

Fiorini Z, Jasoni CL (2010) A novel developmental role for kisspeptin in the growth of gonadotrophin-releasing hormone neurites to the median eminence in the mouse. J Neuroendocrinol 22:1113-1125. CrossRef Medline

Fueshko S, Wray S (1994) LHRH cells migrate on peripherin fibers in embryonic olfactory explant cultures: an in vitro model for neurophilic neuronal migration. Dev Biol 166:331-348. CrossRef Medline

Gamble JA, Karunadasa DK, Pape JR, Skynner MJ, Todman MG, Bicknell RJ, Allen JP, Herbison AE (2005) Disruption of ephrin signaling associates with disordered axophilic migration of the gonadotropin-releasing hormone neurons. J Neurosci 25:3142-3150. CrossRef Medline

Gardiner NJ, Fernyhough P, Tomlinson DR, Mayer U, von der Mark H, Streuli CH (2005) Alpha7 integrin mediates neurite outgrowth of distinct populations of adult sensory neurons. Mol Cell Neurosci 28:229 240. CrossRef Medline

Gardiner NJ, Moffatt S, Fernyhough P, Humphries MJ, Streuli CH, Tomlinson DR (2007) Preconditioning injury-induced neurite outgrowth of adult rat sensory neurons on fibronectin is mediated by mobilisation of axonal alpha5 integrin. Mol Cell Neurosci 35:249-260. CrossRef Medline

Giacobini P, Messina A, Morello F, Ferraris N, Corso S, Penachioni J, Giordano S, Tamagnone L, Fasolo A (2008) Semaphorin 4D regulates gonadotropin hormone-releasing hormone-1 neuronal migration through PlexinB1-Met complex. J Cell Biol 183:555-566. CrossRef Medline

Gibson MJ, Ingraham L, Dobrjansky A (2000) Soluble factors guide gonadotropin-releasing hormone axonal targeting to the median eminence. Endocrinology 141:3065-3071. CrossRef Medline

Gill JC, Tsai PS (2006) Expression of a dominant negative FGF receptor in developing GNRH1 neurons disrupts axon outgrowth and targeting to the median eminence. Biol Reprod 74:463-472. CrossRef Medline

Graus-Porta D, Blaess S, Senften M, Littlewood-Evans A, Damsky C, Huang Z, Orban P, Klein R, Schittny JC, Müller U (2001) Beta1-class integrins regulate the development of laminae and folia in the cerebral and cerebellar cortex. Neuron 31:367-379. CrossRef Medline

Hamilton DL, Abremski K (1984) Site-specific recombination by the bacteriophage P1 lox-Cre system. Cre-mediated synapsis of two lox sites. J Mol Biol 178:481-486. CrossRef Medline

Hanchate NK, Parkash J, Bellefontaine N, Mazur D, Colledge WH, d'Anglemont de Tassigny X, Prevot V (2012) Kisspeptin-GPR54 signaling in mouse NO-synthesizing neurons participates in the hypothalamic control of ovulation. J Neurosci 32:932-945. CrossRef Medline

Huang Z, Shimazu K, Woo NH, Zang K, Müller U, Lu B, Reichardt LF (2006) Distinct roles of the beta 1-class integrins at the developing and the mature hippocampal excitatory synapse. J Neurosci 26:11208-11219. CrossRef Medline

Hynes RO (2002) Integrins: bidirectional, allosteric signaling machines. Cell 110:673-687. CrossRef Medline

Jarzab B, Döhler KD (1984) Serotoninergic influences on sexual differentiation of the rat brain. Prog Brain Res 61:119-126. CrossRef Medline

Khan KN, Masuzaki H, Fujishita A, Kitajima M, Sekine I, Matsuyama T, 
Ishimaru T (2005) Estrogen and progesterone receptor expression in macrophages and regulation of hepatocyte growth factor by ovarian steroids in women with endometriosis. Hum Reprod 20:2004-2013. CrossRef Medline

Kumar TR, Wang Y, Lu N, Matzuk MM (1997) Follicle stimulating hormone is required for ovarian follicle maturation but not male fertility. Nat Genet 15:201-204. CrossRef Medline

Lilienbaum A, Reszka AA, Horwitz AF, Holt CE (1995) Chimeric integrins expressed in retinal ganglion cells impair process outgrowth in vivo. Mol Cell Neurosci 6:139-152. CrossRef Medline

Lim H, Paria BC, Das SK, Dinchuk JE, Langenbach R, Trzaskos JM, Dey SK (1997) Multiple female reproductive failures in cyclooxygenase 2-deficient mice. Cell 91:197-208. CrossRef Medline

Liu Y, Lin L, Zarnegar R (1994) Modulation of hepatocyte growth factor gene expression by estrogen in mouse ovary. Mol Cell Endocrinol 104: 173-181. CrossRef Medline

Lydon JP, DeMayo FJ, Conneely OM, O’Malley BW (1996) Reproductive phenotypes of the progesterone receptor null mutant mouse. J Steroid Biochem Mol Biol 56:67-77. CrossRef Medline

Maric D, Maric I, Chang YH, Barker JL (2003) Prospective cell sorting of embryonic rat neural stem cells and neuronal and glial progenitors reveals selective effects of basic fibroblast growth factor and epidermal growth factor on self-renewal and differentiation. J Neurosci 23:240-251. Medline

Messina A, Ferraris N, Wray S, Cagnoni G, Donohue DE, Casoni F, Kramer PR, Derijck AA, Adolfs Y, Fasolo A, Pasterkamp RJ, Giacobini P (2011) Dysregulation of Semaphorin7A/betal-integrin signaling leads to defective GnRH-1 cell migration, abnormal gonadal development and altered fertility. Hum Mol Genet 20:4759-4774. CrossRef Medline

Moresco EM, Donaldson S, Williamson A, Koleske AJ (2005) Integrinmediated dendrite branch maintenance requires Abelson (Abl) family kinases. J Neurosci 25:6105-6118. CrossRef Medline

Moser M, Legate KR, Zent R, Fässler R (2009) The tail of integrins, talin, and kindlins. Science 324:895-899. CrossRef Medline

Nguyen H, Ivanova VS, Kavandi L, Rodriguez GC, Maxwell GL, Syed V (2011) Progesterone and 1,25-dihydroxyvitamin D(3) inhibit endometrial cancer cell growth by upregulating semaphorin $3 \mathrm{~B}$ and semaphorin 3F. Mol Cancer Res 9:1479-1492. CrossRef Medline

Nikolova Z, Djonov V, Zuercher G, Andres AC, Ziemiecki A (1998) Celltype specific and estrogen dependent expression of the receptor tyrosine kinase EphB4 and its ligand ephrin-B2 during mammary gland morphogenesis. J Cell Sci 111(Pt 18):2741-2751.

Ojeda SR, Skinner MK (2006) Puberty in the rat. In: Knobil and Neill's Physiology of Reproduction, Ed 3 (Neill JD, ed.), pp 2061-2126. New York: Elsevier.

Pasterkamp RJ, Peschon JJ, Spriggs MK, Kolodkin AL (2003) Semaphorin 7A promotes axon outgrowth through integrins and MAPKs. Nature 424: 398-405. CrossRef Medline

Pavelock K, Braas K, Ouafik L, Osol G, May V (2001) Differential expression and regulation of the vascular endothelial growth factor receptors neuropilin-1 and neuropilin-2 in rat uterus. Endocrinology 142:613-622. CrossRef Medline

Pfaff M, McLane MA, Beviglia L, Niewiarowski S, Timpl R (1994) Comparison of disintegrins with limited variation in the RGD loop in their binding to purified integrins alpha IIb beta 3 , alpha $\mathrm{V}$ beta 3 and alpha 5 beta 1 and in cell adhesion inhibition. Cell Adhes Commun 2:491-501. CrossRef Medline

Pinkstaff JK, Detterich J, Lynch G, Gall C (1999) Integrin subunit gene expression is regionally differentiated in adult brain. J Neurosci 19:15411556. Medline

Plantman S, Patarroyo M, Fried K, Domogatskaya A, Tryggvason K, Hammarberg H, Cullheim S (2008) Integrin-laminin interactions control- ling neurite outgrowth from adult DRG neurons in vitro. Mol Cell Neurosci 39:50-62. CrossRef Medline

Prevot V, Lomniczi A, Corfas G, Ojeda SR (2005) erbB-1 and erbB-4 receptors act in concert to facilitate female sexual development and mature reproductive function. Endocrinology 146:1465-1472. Medline

Reichardt LF, Tomaselli KJ (1991) Extracellular matrix molecules and their receptors: functions in neural development. Annu Rev Neurosci 14:531570. CrossRef Medline

Richeri A, Chalar C, Martínez G, Greif G, Bianchimano P, Brauer MM (2011) Estrogen up-regulation of semaphorin $3 \mathrm{~F}$ correlates with sympathetic denervation of the rat uterus. Auton Neurosci 164:43-50. CrossRef Medline

Schwanzel-Fukuda M, Pfaff DW (1989) Origin of luteinizing hormonereleasing hormone neurons. Nature 338:161-164. CrossRef Medline

Schwarting GA, Raitcheva D, Bless EP, Ackerman SL, Tobet S (2004) Netrin 1-mediated chemoattraction regulates the migratory pathway of LHRH neurons. Eur J Neurosci 19:11-20. CrossRef Medline

Simerly RB (1998) Organization and regulation of sexually dimorphic neuroendocrine pathways. Behav Brain Res 92:195-203. CrossRef Medline

Simerly RB (2002) Wired for reproduction: organization and development of sexually dimorphic circuits in the mammalian forebrain. Annu Rev Neurosci 25:507-536. CrossRef Medline

Singh P, Chen C, Pal-Ghosh S, Stepp MA, Sheppard D, Van De Water L (2009) Loss of integrin alpha9betal results in defects in proliferation, causing poor re-epithelialization during cutaneous wound healing. J Invest Dermatol 129:217-228. CrossRef Medline

Spergel DJ, Krüth U, Hanley DF, Sprengel R, Seeburg PH (1999) GABAand glutamate-activated channels in green fluorescent protein-tagged gonadotropin-releasing hormone neurons in transgenic mice. J Neurosci 19:2037-2050. Medline

Stephens LE, Sutherland AE, Klimanskaya IV, Andrieux A, Meneses J, Pedersen RA, Damsky CH (1995) Deletion of beta 1 integrins in mice results in inner cell mass failure and peri-implantation lethality. Genes Dev 9:1883-1895. CrossRef Medline

Tobet S, Knoll JG, Hartshorn C, Aurand E, Stratton M, Kumar P, Searcy B, McClellan K (2009) Brain sex differences and hormone influences: a moving experience? J Neuroendocrinol 21:387-392. CrossRef Medline

Tsai PS, Moenter SM, Postigo HR, El Majdoubi M, Pak TR, Gill JC, Paruthiyil S, Werner S, Weiner RI (2005) Targeted expression of a dominantnegative fibroblast growth factor (FGF) receptor in gonadotropinreleasing hormone $(\mathrm{GnRH})$ neurons reduces FGF responsiveness and the size of GnRH neuronal population. Mol Endocrinol 19:225-236. Medline

Warren MS, Bradley WD, Gourley SL, Lin YC, Simpson MA, Reichardt LF, Greer CA, Taylor JR, Koleske AJ (2012) Integrin betal signals through Arg to regulate postnatal dendritic arborization, synapse density, and behavior. J Neurosci 32:2824-2834. CrossRef Medline

Webb DJ, Zhang H, Majumdar D, Horwitz AF (2007) alpha5 integrin signaling regulates the formation of spines and synapses in hippocampal neurons. J Biol Chem 282:6929-6935. Medline

Wierman ME, Kiseljak-Vassiliades K, Tobet S (2011) Gonadotropinreleasing hormone $(\mathrm{GnRH})$ neuron migration: initiation, maintenance and cessation as critical steps to ensure normal reproductive function. Front Neuroendocrinol 32:43-52. CrossRef Medline

Wray S (2010) From nose to brain: development of gonadotrophinreleasing hormone-1 neurones. J Neuroendocrinol 22:743-753. CrossRef Medline

Wray S, Grant P, Gainer H (1989) Evidence that cells expressing luteinizing hormone-releasing hormone mRNA in the mouse are derived from progenitor cells in the olfactory placode. Proc Natl Acad Sci U S A 86:81328136. CrossRef Medline

Yoon H, Enquist LW, Dulac C (2005) Olfactory inputs to hypothalamic neurons controlling reproduction and fertility. Cell 123:669-682. CrossRef Medline 